\title{
Modelling nutrient retention in the coastal zone of an eutrophic sea
}

\author{
Elin Almroth-Rosell ${ }^{1}$, Moa Edman ${ }^{1}$, Kari Eilola ${ }^{1}$, H. E. Markus Meier ${ }^{1,2}$, and Jörgen Sahlberg ${ }^{1}$ \\ ${ }^{1}$ Swedish Meteorological and Hydrological Institute, Norrköping, Sweden \\ ${ }^{2}$ Leibniz Institute for Baltic Sea Research Warnemünde, Rostock, Germany \\ Correspondence to: Elin Almroth-Rosell (elin.almroth.rosell@smhi.se)
}

Received: 12 February 2016 - Published in Biogeosciences Discuss.: 26 February 2016

Revised: 10 September 2016 - Accepted: 21 September 2016 - Published: 18 October 2016

\begin{abstract}
The Swedish Coastal zone Model (SCM) was used at a test site, the Stockholm archipelago, located in the northern part of the central Baltic Sea, to study the retention capacity of the coastal filter on nitrogen $(\mathrm{N})$ and phosphorus (P) loads from land and atmosphere. The efficiency of the coastal filter to permanently retain nutrients determines how much of the local nutrient loads actually reach the open sea. The SCM system is a nutrient-phytoplanktonzooplankton-detritus-type model coupled to a horizontally integrated, physical model in particular suitable for estuaries. In this study the Stockholm Archipelago, consisting of 86 sub-basins, was divided into three sub-areas: the inner, the intermediate and the outer archipelago. An evaluation of model results showed that the modelled freshwater supply agrees well with observations. The nutrient, salinity and temperature dynamics simulated by the SCM are also found to be in good or acceptable agreement with observations. The analysis showed that the Stockholm Archipelago works as a filter for nutrients that enter the coastal zone from land, but the filter efficiency is not effective enough to retain all the supplied nutrients. However, at least 65 and $72 \%$ of the P and $\mathrm{N}$, respectively, are retained during the studied period (19902012). A major part of the retention is permanent, which for $\mathrm{P}$ means burial. For N, almost $92 \%$ of the permanent retention is represented by benthic denitrification, less than $8 \%$ by burial, while pelagic denitrification is below $1 \%$. Highest total amounts of $\mathrm{P}$ and $\mathrm{N}$ are retained in the outer archipelago, where the surface area is largest. The area-specific retention of $\mathrm{P}$ and $\mathrm{N}$, however, is highest in the smaller inner archipelago and decreases towards the open sea. A reduction scenario of the land loads of $\mathrm{N}$ and $\mathrm{P}$ showed that the filter efficiencies of $\mathrm{N}$ and $\mathrm{P}$ increase and the export of $\mathrm{N}$ from the
\end{abstract}

archipelago decreases. About 15 years after the reduction, the export of $\mathrm{P}$ changes into an import of $\mathrm{P}$ from the open sea to the archipelago.

\section{Introduction}

The worldwide increase in coastal eutrophication and anoxia has spread exponentially since the 1960s. Coastal oxygen depletion is associated with dense population areas and large river loads of nutrients (Diaz and Rosenberg, 2008). The use of industrially produced fertilizer started in the late 1940s and has since then been contributing to the anthropogenic fertilization of the global marine system (Galloway et al., 2008). The river load of nutrients originating from agriculture activities has been shown to be controlled by the size of the river flow; for example, the flow from the Mississippi River has a large impact on the oxygen conditions in the northern Gulf of Mexico, which suffers from severe hypoxia with "dead zones" as a result (Rabalais et al., 2002).

With the goal of diminishing eutrophication there have been numerous efforts around the world to reduce the land load of nutrients to sea, but the expected results of a healthier environment have not been accomplished in all places (Kemp et al., 2009). The responses of eutrophication and the extent of hypoxic area for changes in nutrient loads are different in different types of systems. Also, changes in climatic and hydrodynamic conditions might lead to a non-linear recovery (Kemp et al., 2009). Nutrients transported from land to sea first enter the coastal zones and are then further transported towards the open sea. However, not all of the supplied nutrients reach the open sea as they are retained in the coastal 


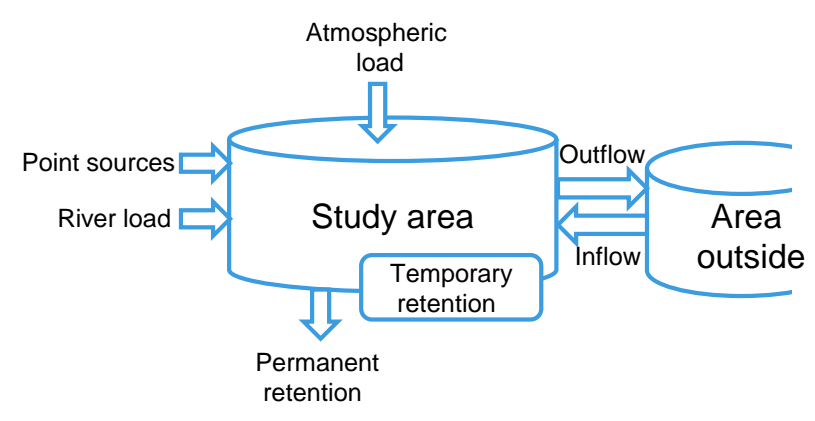

Figure 1. Simplified scheme of the retention calculations in the study area. Permanent retention is considered a permanent removal of nutrients from the ecological system and includes burial and, for nitrogen, also denitrification. Temporary retention is defined as the changes in nutrient inventory in the active sediment layer and water column. The temporary retention may change sign depending on whether the nutrient inventory increases or declines.

zone (Fig. 1), which acts as a filter (McGlathery et al., 2007). The retention capacity depends on different chemical, physical and/or biological processes that involve nutrients, e.g. denitrification, permanent burial, algae and plant assimilation (Duarte and Cebrián, 1996; Voss et al., 2005). The filter efficiency of the coastal zone might be of large importance for the water quality in open waters.

Retention capacity is, however, not well defined. Johnston (1991) discussed that retention processes are of different magnitudes and irreversibility; for example, plant uptake and litter decomposition provide short- to long-term retention of nutrients. Billen et al. (2011) and Nixon et al. (1996) defined retention as the net effect of temporary and permanent removal from the water phase through different biogeochemical processes. Burial and denitrification lead to a permanent removal of nutrients from the ecological system (Voss et al., 2005). Plant assimilation of nutrients and sedimentation of organic material might influence the temporary retention, defined as a build-up of active nutrient pools in the water and in the sediment. Some of the organic material is more refractory than others, e.g. parts of root systems, which also can influence biogeochemical processes by enhanced sediment oxygen, nutrient and dissolved organic material concentrations (McGlathery et al., 2007). Thus, temporary retention depends on the release rates, translocations, and the longevity of plants, which causes variations in retention capacity depending on the timescale of the study. The net effect of nutrient retention in an area can be studied using the simple method of subtracting the output of nutrients from the input (Johnston, 1991). This simple method of calculating the retention capacity of nitrogen $(\mathrm{N})$ and phosphorus $(\mathrm{P})$ has been used in a number of studies (e.g. Eilola et al., 2014; Hayn et al., 2014; Karlsson et al., 2010; Nixon et al., 1996; Sanders et al., 1997) for different areas of the world. The retention capacity has been discussed to be related to the residence time and depth in different water systems (Balls, 1994; Hayn et
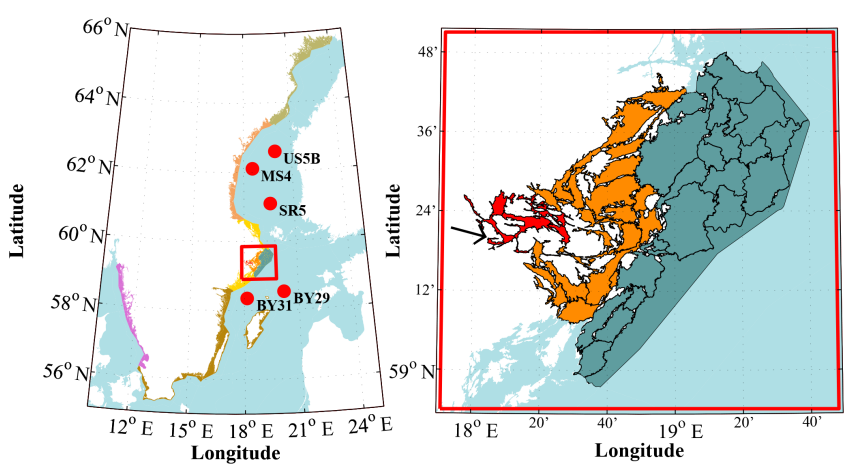

Figure 2. The Swedish Coastal zone Model can be used in different areas along the Swedish coast, stretching from the Norwegian border in the west to the Finnish border in the north (different colours, left). In the present study the SCM covers the northern Baltic proper (marked with a red square) and has been used to estimate the coastal filter efficiency of nutrients in the Stockholm inner (red), intermediate (orange) and outer (blue) archipelagos (right). The outlet of the river Norrström is marked by a black arrow and the different basins are shown by the black contours.

al., 2014; Nixon et al., 1996). Hence, the longer a water parcel and its nutrient content stays within a system, the more the containing nutrients are affected by the internal transformation and retention processes.

In the present study, filter efficiency is explained as the capacity of the studied area to retain the local nutrient loads from land and atmosphere (see Sect. 2.4). A distinction is made between the permanent removal and temporal retention, of which the latter is caused by changes in the $\mathrm{N}$ and $\mathrm{P}$ inventory (Fig. 1). There are studies of nutrient retention in different coastal zones around the world, but there are not enough estimates to evaluate and understand its effect on the environmental status of coastal seas. Quantification of the filter efficiencies in different coastal ecosystems as estuaries, archipelagos, lagoons and embayments would increase the understanding and the knowledge necessary for managing the coastal zone. Numerical models have been used to a larger extent for studies in lakes and freshwater catchment areas (e.g. Ahlgren et al., 1988; Hejzlar et al., 2009) than for retention and filter efficiency studies in coastal areas, where only a few studies seem to exist in the literature (e.g. Fennel et al., 2006; Seitzinger and Giblin, 1996; Xue et al., 2013).

The Baltic Sea (Fig. 2), located in northern Europe, is an example of where the enhanced land load of nutrients to the sea (Gustafsson et al., 2012) has led to eutrophication and consequently increased frequency and intensity of cyanobacterial blooms, expanding bottom hypoxia and dead bottom zones (e.g. Bergström et al., 2001; Conley et al., 2009; Diaz and Rosenberg, 2008; Vahtera et al., 2007). In fact, the largest anthropogenically induced hypoxic area in the world is found in the Baltic Sea (Carstensen et al., 2014), where it varied between 70000 and $80000 \mathrm{~km}^{2}$ during the years 2010-2014 (Hansson and Andersson, 2014). In the Baltic Sea, most of 
the coastal zones and the open sea still suffer from eutrophication in spite of reduced nutrient loads since the 1990s (HELCOM, 2010).

The aim of this study is to quantify the filter efficiency in the eutrophic Stockholm Archipelago (see Sect. 2.1) of N and $\mathrm{P}$ and to discuss the relative importance of different physical and/or biological processes using the Swedish Coastal zone Model (SCM). In addition, changes in the filter efficiency along the land-sea continuum, from the inner archipelago to the intermediate and outer archipelago and then to the open Baltic Sea, will be studied in order to evaluate the effect of the size of the archipelago on the filter efficiency.

After a description of the model system (Sect. 2) and an evaluation of the results of SCM (Sect. 3.1), the filter efficiency of the coastal zone is calculated and the effects of a reduced land load of N and P are analysed (Sect. 3.2). Conclusions finalize the study (Sect. 4).

\section{Methods}

\subsection{Study site}

The brackish archipelago of Stockholm (Fig. 2), located at the east coast of Sweden, is the largest archipelago in Sweden and the second largest in the Baltic Sea. The archipelago is a continuation of the river Norrström with an average discharge of about $160 \mathrm{~m}^{3} \mathrm{~s}^{-1}$ from Lake Mälaren (Lindh, 2013). The river outflow carries about $2600 \mathrm{t}$ of $\mathrm{N}$ and $120 \mathrm{t}$ of P annually to the coastal basin "Strömmen" in the inner archipelago (Lännergren, 2010). The rocky islands in the archipelago are surrounded by basins of different sizes and depths which are connected by straits. In this study the archipelago has been divided into three areas: the inner, intermediate and outer archipelagos. Several large islands form a natural border between the inner and the intermediate archipelagos, and the limited water exchange occurs through five narrow sounds with shallow sills. The outflow from the inner to the intermediate archipelago passes through the sounds in the surface layer, while inflows of more saline water mainly occur at larger depths. The border between the intermediate and the outer archipelagos follows the chain of islands in the north-south direction, with several connections between the areas (Fig. 2).

The largest point sources of nutrients to the inner archipelago originate from waste-water treatment facilities of Stockholm, which is situated at the outlet of the Lake Mälaren. Signs of eutrophication in the Stockholm Archipelago have been observed as an increased ratio of laminated sediments since the 1930s (Jonsson et al., 2003) and the eutrophication status in the inner Stockholm Archipelago was classified as highly eutrophic in the early 1970s (Lännergren et al., 2009). In the 1970s the sewage treatment facilities in Stockholm started to chemically precipitate $\mathrm{P}$, which reduced their P load from about 600 to about $100 \mathrm{t} \mathrm{yr}^{-1}$ (Fig. 3

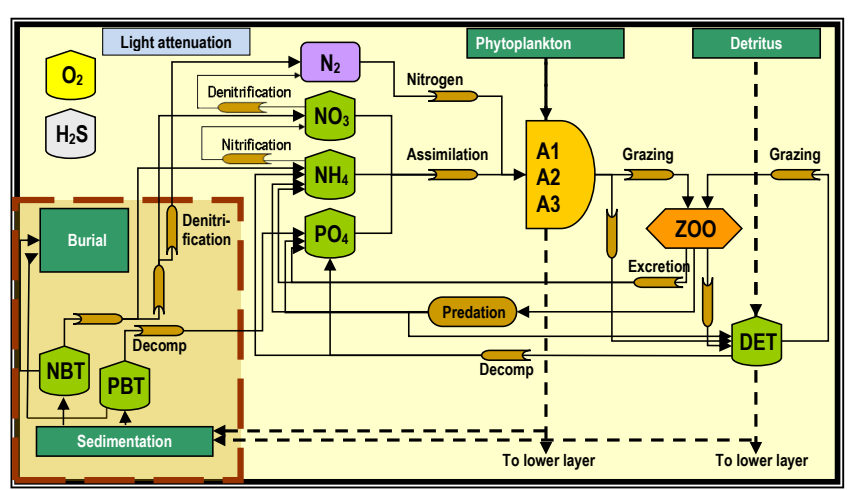

Figure 3. Schematic figure of the Swedish COastal and BIogeochemical model, SCOBI. Oxygen and hydrogen sulfide are simplified for clarity.

in Lücke, 2014). The reduction led to some improvements in the marine environment (Brattberg, 1986), but in the 1990s the areas were still eutrophic, with poor bottom water oxygen conditions (Jonsson et al., 2003; Rosenberg and Diaz, 1993). In the mid-1990s there was a further reduction in the $\mathrm{P}$ to about $25 \mathrm{t} \mathrm{yr}^{-1}$ and the sewage treatment facilities started to reduce the $\mathrm{N}$ as well, from about 3000 to $1250 \mathrm{t} \mathrm{yr}^{-1}$ (Fig. 3 in Lücke, 2014), which led to further improvement in the eutrophication status. In 2008 the bottom oxygen conditions had clearly improved in the deeper parts, and only enclosed bays, such as Stora Värtan, still suffered from anoxia (Karlsson et al., 2010, and references therein). However, the annual monitoring status report of the environmental status of the inner Stockholm Archipelago in 2014 still classified the area as unsatisfactorily eutrophic (Lücke, 2015) according to the national directives by the Swedish Environmental Protection Agency and the Swedish Agency for Marine and Water Management (Naturvårdsverket, 2007; HaV, 2013) based on the EU Water Framework Directive. The area still suffered from reduced water transparency, high concentrations of phytoplankton chlorophyll and areas without any bottom fauna due to low oxygen concentrations.

\subsection{Model description}

The SCM is a multi-basin 1-D model based on the equation solver PROgram for Boundary layers in the Environment (PROBE; Svensson, 1998), coupled to the Swedish Coastal and Ocean Biogeochemical model (SCOBI; Eilola et al., 2009; Marmefelt et al., 1999). The model system was developed to calculate physical and biogeochemical states in Swedish coastal waters. The inner, intermediate and outer Stockholm archipelagoes (Fig. 2) are represented by 16, 44 and 26 sub-basins, respectively (see Fig. S1 in the Supplement). 


\subsubsection{PROBE}

The physical model PROBE calculates horizontal velocities, temperature and salinity profiles (Svensson, 1998; Omstedt, 2015). The surface mixing is calculated by a $k \varepsilon$ turbulence model and the bottom mixing is a parameterization based on the stability in the bottom water. Light transmission, as well as ice formation growth and decay, is also included in the model. The vertical grid resolution is $0.5 \mathrm{~m}$ in the uppermost layers, $1 \mathrm{~m}$ from 4 to $70 \mathrm{~m}$, and $2 \mathrm{~m}$ between 70 and $100 \mathrm{~m}$. The general differential equation of the PROBE solver is formally written as

$\frac{\partial \phi}{\partial t}+\frac{\partial}{\partial x_{i}} u_{i} \phi=\frac{\partial}{\partial z}\left(\Gamma_{\phi} \frac{\partial \phi}{\partial z}\right)+S_{\phi}$,

where $\varphi$ is the dependent variable, $t$ is time, $z$ is the vertical coordinate, $x_{i}$ represents the horizontal coordinates, $u_{i}$ represents horizontal velocities, $\Gamma_{\varphi}$ is the vertical exchange coefficient, and $S_{\varphi}$ represents source and sink terms. Vertical advection (and moving surface) is included accounting for vertical transport in sub-basins due to in- and outflows. The sources and sinks determined by the ecosystem model are added to $S_{\varphi}$.

The water exchange between the sub-basins is controlled by the baroclinic pressure gradients. The net flow through the sounds will be the same as the river discharge from land in order to preserve volume. Inflowing water to a sub-basin is interleaved into its density level without any entrainment, and heavy surface water in one sub-basin may thus reach the bottom level in an adjacent basin. The sea level variations outside the boundary are of minor importance for the SCM results and are therefore not included in the forcing. The water exchange across the boundary between the coastal zone and the open sea is assumed to be in geostrophic balance, since this boundary is open with a width greater than the internal Rossby radius. A time step of $600 \mathrm{~s}$ was used in the present simulations.

\subsubsection{Biogeochemical model (SCOBI)}

The SCOBI model describes the biogeochemistry of marine waters in the Baltic Sea and Kattegat (Eilola et al., 2009). Nine pelagic and two benthic variables (Fig. 3) are described in the SCM-SCOBI model. In the pelagic zone three different phytoplankton groups (diatoms, flagellates and others, and cyanobacteria), one zooplankton group, one pool for detritus and three inorganic nutrients pools (nitrate, ammonium and phosphate) are represented. The model also calculates oxygen and hydrogen sulfide concentrations, of which the latter are represented by "negative oxygen" equivalents $\left(1 \mathrm{~mL} \mathrm{H}_{2} \mathrm{~S} \mathrm{~L}^{-1}=-2 \mathrm{~mL} \mathrm{O}_{2} \mathrm{~L}^{-1}\right.$ ), and includes the conversion of sulfate into hydrogen sulfide (Fonselius, 1969). Thus, the negative oxygen corresponds to the amount of oxygen needed to oxidize the hydrogen sulfide. The sediment in the present model is parameterized by one vertically integrated bulk sediment layer (level 3 in Soetaert et al., 2000). Organic material that sinks to the sediment is divided into one benthic nitrogen pool (NBT) and one benthic phosphorus pool (PBT). SCOBI has been used and validated in several studies, coupled to both the basin-scale Baltic Sea model PROBE-Baltic (e.g. Marmefelt et al., 1999) and to the threedimensional Rossby Centre Ocean model (RCO; e.g. Meier et al., 2011).

In the model the following processes are described: phytoplankton assimilation; phytoplankton mortality; nitrogen fixation; zooplankton grazing; zooplankton excretion of detritus, dissolved inorganic nitrogen (DIN) and phosphorus (DIP); oxygen- and temperature-dependent mineralization of detritus, benthic $\mathrm{N}$ and benthic $\mathrm{P}$; and oxygen- and temperature-dependent nitrification and denitrification. Phytoplankton assimilates carbon (C), $\mathrm{N}$ and $\mathrm{P}$ according to the Redfield molar ratio $(\mathrm{C}: \mathrm{N}: \mathrm{P}=106: 16: 1)$ and the biomass is represented by chlorophyll (Chl) according to a constant carbon to chlorophyll mass $(\mathrm{mg})$ ratio $(\mathrm{C}: \mathrm{Chl}=50: 1)$. Light attenuation depends on background attenuation due to water and humic substances and a variable attenuation caused by particulate organic matter (phytoplankton, zooplankton and detritus). All particulate variables sink downward through the water column. Predation is used as a closing term to parameterize interactions with higher tropic levels in the ecosystem and move matter from zooplankton to the detrital and inorganic pools. Resuspension of sediment that is important in the open Baltic Sea (Almroth-Rosell et al., 2011) has not yet been implemented in this SCOBI version, but the sediment releases dissolved inorganic nutrients back to the water mass, with the release of phosphate being redox-dependent. Some fractions of benthic $\mathrm{N}$ and $\mathrm{P}$ are assumed to be buried in the sediment as a permanent sink and are hence removed from the system. For further details of the SCOBI model, the reader is referred to Eilola et al. (2009, 2011).

\subsubsection{Forcing}

The SCM-SCOBI model system is forced by weather, the conditions in the sea outside the archipelago, point sources, discharge of freshwater and nutrients from land, and atmospheric deposition of nutrients. The initial values for both the pelagic zone and the sediment are derived from spin-up simulations.

There are two types of land-derived forcing; discharge of water and nutrients from both rivers and surface runoff from the drainage area given by the S-HYPE model (Lindström et al., 2010) and point sources representing sewage plants and industries. The runoff is added to the surface water of each basin and no reduction in river nutrients due to precipitation at river mouths is assumed in this model setup. The point sources of nutrient loads are assigned to the depth levels mostly resembling the actual depth of the discharge. 
The inorganic riverine nutrient loads are added as DIN and DIP to the SCM. The organic nutrients in the land loads are calculated from the difference between total nitrogen (TN) and DIN and between total phosphorus (TP) and DIP. The bioavailability and the composition (dissolved or particulate) of the organic nitrogen and phosphorus loading from land are generally not known. In the present model configuration the fraction of organic nutrient loads that follows the Redfield ratio is assumed to be bioavailable and will be added to the detritus pool in the model, while the remaining fractions of nutrient loads are treated as conservative tracers in the model.

The weather forcing consists of solar insolation, air temperature, wind, relative humidity and cloudiness. The insolation and all the radiation and heat fluxes across the water-air interface are calculated by the PROBE model. The weather variables are taken from a gridded database developed at the Swedish Meteorological and Hydrological Institute (SMHI), using 3-hourly meteorological synoptic monitoring station data, and the depositions of nitrogen species (NHX and NOX) are calculated by the MATCH model (Robertson et al., 1999). For the deposition of phosphate, a literature value of $0.5 \mathrm{~kg} \mathrm{~m}^{-2} \mathrm{month}^{-1}$ is used (Areskoug, 1993).

The boundary conditions to the open Baltic Sea is set by vertical mean profiles calculated by a one-dimensional PROBE setup for each Baltic open-water area and assimilation of monitoring data. The monitoring data used in the assimilation are extracted from the stations MS4, US5B, SR5, BY31 and BY29 (Fig. 2) depending on depth and time, to get the best representation of the open sea's influence on the SCM model domain.

\subsection{Evaluation strategy}

To quantify the fit between modelled values and observations a correlation coefficient, $r$, was calculated (Eq. 2).

$$
r=\frac{\sum_{i=1}^{n}\left(P_{i}-\bar{P}\right)\left(O_{i}-\bar{O}\right)}{\sqrt{\sum_{i=1}^{n}\left(P_{i}-\bar{P}\right)^{2} \sum_{i=1}^{n}\left(O_{i}-\bar{O}\right)^{2}}},
$$

where $P$ is the model value, $O$ is the observation of the analysed parameter, $i$ is the data number and $n$ is the total number of data points. Two series of observations and model values that are identical will lead to an $r$ value equal to one, while uncorrelated data result in a $r$ value close to zero. In addition to the $r$ value, the average cost function $(C)$ values (Eq. 3) for the different parameters were used in the evaluation of the SCM results.

$C=\frac{\sum_{i=1}^{n}\left|\frac{P_{i}-O_{i}}{\operatorname{SD}\left(O_{i}\right)}\right|}{n}$

A cost function describes the proximity of model results and observations by normalizing the difference between them

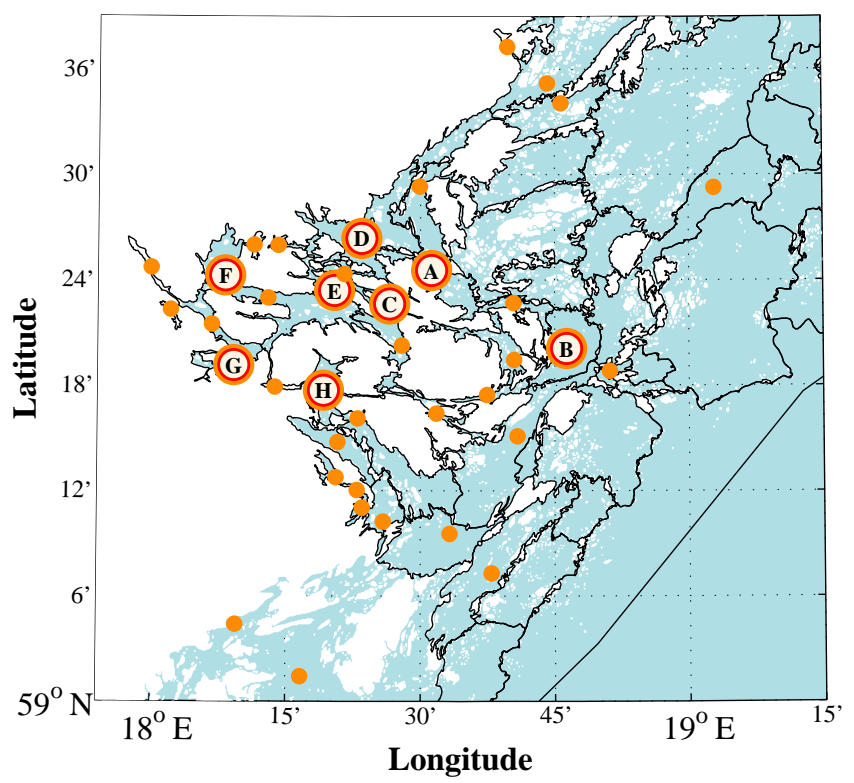

Figure 4. Available locations with observations (circles and dots) in the Stockholm Archipelago. Model evaluation of temperature, salinity, DIN, DIP and bottom water oxygen concentration was performed at selected stations (circles marked with letters), which are described in Table 1.

with the standard deviation (SD) of the observations. If average model results fall within the standard deviation of observations, $C$ is below one, which is regarded as good. Results that are within 2 standard deviations will be regarded as at an acceptable level. The corresponding simulation levels, good and acceptable, for the correlation coefficient are achieved when $r$ is higher than two-thirds (0.66) and one-third (0.33), respectively. This approach using $r$ and $C$ has been used in earlier studies (Edman and Omstedt, 2013; Edman and Anderson, 2014) and is based on methods by Oschlies (2010).

The outflow from Lake Mälaren is 3 orders of magnitude larger than the sum of all other S-HYPE freshwater components to the inner Stockholm Archipelago. The output from S-HYPE of freshwater and nutrient loads from Mälaren to the Stockholm Archipelago was therefore used in the evaluation of the freshwater forcing to SCM. Observations of freshwater discharge were retrieved from the Baltic Environmental Database (BED, 2015) at the Baltic Nest Institute, Stockholm University. The correlation between the monthly mean of observed and simulated discharge for the period (1990 2012) was then calculated.

In the evaluation of the results of the SCM in different basins, the long-term averages (1990-2012) of the vertical distribution of salinity, DIN, DIP and oxygen during winter (November-February) and summer months (May-August) were compared to corresponding observations for the whole modelled period. Further, the correlation $r$ and the mean cost function $C$ of the vertical distribution of observations and model output were calculated. Also, the long-term averages 
Table 1. Number of sampling occasions (Occ) during the number of years, number of months during each year, and number of depth levels that were frequently sampled at the different stations used for validation of model results. The position of the stations can be seen in Fig. 4 .

\begin{tabular}{lllcccc}
\hline ID & Station name & Basin name & Occ & Years $^{1}$ & Months & Depths $^{2}$ \\
\hline A & Nyvarp & Sandöfjärden & 209 & 23 & 8 & 14 \\
B & Kanholmsfjärden & Kanholmsfjärden & 206 & 23 & 9 & 13 \\
C & Solöfjärden & Solöfjärden & 213 & 23 & 8 & 14 \\
D & TrälhavetII & Trälhavet & 215 & 23 & 9 & 13 \\
E & S. Vaxholmsfjärden & S. Vaxholmsfjärden & 131 & 23 & 7 & 8 \\
F & Blomskär & Stora Värtan & 141 & 23 & 8 & 9 \\
G & Blockhusudden & Strömmen & 249 & 23 & 11 & 16 \\
H & Baggensfjärden & Baggensfjärden & 173 & 20 & 9 & 10 \\
\hline
\end{tabular}

${ }^{1}$ Entire period is 23 years. ${ }^{2}$ Sampled on at least half of the sample occasions.

of the seasonal variations in surface temperature, DIN, DIP and bottom water oxygen concentrations were used in the evaluation by calculating the corresponding $r$ and $C$ values.

Observations from the Stockholm Archipelago (Fig. 4) were provided by Stockholm City and Stockholm University. For the quantitative validation described above, the quality of observations from each site (Table 1) had to fulfil three requirements to be used in the validation process: (1) period coverage $-80 \%$ of the years sampled; (2) annual coverage - at least 7 of the 12 months sampled; and (3) vertical data coverage - at least five depth levels frequently measured over the full depth of the basin. In addition at least 3 months with observations were required for the evaluation of winter and summer conditions. Average values were then calculated for periods and depth levels with dense data distribution. The model output was used in the same way as observations, and the modelled averages were calculated for the same time intervals and depth ranges.

\subsection{Calculation of retention}

The retention of $\mathrm{P}$ and $\mathrm{N}$ in a region can be calculated as the difference between the load and the outflow (Almroth-Rosell et al., 2015; Hayn et al., 2014; Johnston, 1991; Meier et al., 2012). The input of nutrients is the sum of inflows from outer areas, rivers, land runoff, point sources and atmospheric load, while the outflow of nutrients is the export from the area to outer seas (Fig. 1). $\mathrm{N}_{2}$ fixation is another process that needs to be taken into account as it is a source of bioavailable $\mathrm{N}$ to the system. Retention in the present study can be temporal or permanent. Permanent retention removes the nutrients permanently from the pool of nutrients in the modelled system. Burial is the only retention process that permanently removes $\mathrm{P}$. For $\mathrm{N}$, in addition to burial, benthic and pelagic denitrification is also considered to be permanent removal. The temporal retention during a studied period can be negative or positive depending on changes in the pelagic and benthic inventory of nutrients. The nutrient pools include both the inorganic and organic nutrients. Factors that affect the benthic $\mathrm{N}$ and $\mathrm{P}$ pools are the sedimentation of organic material from the water column, the decomposition of organic material and the release of inorganic nutrients back to the water column, as well as burial of nutrients. The pelagic $\mathrm{N}$ and $\mathrm{P}$ pools are affected by the supply from land, the export of organic material to the sediment, and the release of nutrients from the sediment to the water column and to the net export of nutrients to downstream areas.

The different processes that affect retention have been calculated separately, as they are included in the biogeochemical model SCOBI. Total retention $\left(R_{\mathrm{tot}}\right)$ is the sum of both permanently and temporally retained $\mathrm{P}$ and N. Area-specific retention, $R_{\mathrm{AS}}$, is the retention normalized to the area and is calculated from Eq. (4):

$R_{\mathrm{AS}}=\frac{R_{\mathrm{tot}}}{A}$,

where $A$ is the size of the area. $R_{\mathrm{AS}}$ can be used to compare the retention in basins of different sizes. The filter efficiency, $F_{\text {eff }}$, is calculated from Eq. (5):

$F_{\text {eff }}=\frac{R_{\text {tot }}}{\mathrm{Nu}_{\text {land }}} \times 100$,

where $\mathrm{Nu}_{\text {land }}$ is the sum of the nutrient load from land and the deposition from air. The $F_{\text {eff }}$ is an estimate of the proportion (\%) of the nutrients from land and atmosphere that is retained within the area. Similarly, the retention efficiency $\left(R_{\text {eff }}\right)$ can also be calculated, defined as the proportion of the total nutrient load (sum of all sources, including import from surrounding waters) that is retained within the area. In the present study, however, the focus is on the filter efficiency.

The total retention efficiency was calculated for the entire Stockholm Archipelago, and also separately for the inner, intermediate and outer archipelagos in order to investigate the spatial gradient of retention capacity from the inner coastal zone towards the open Baltic Sea.

The residence time is defined as the average time water, or a dissolved substance, spends within a particular basin (Bolin and Rodhe, 1973). In the present study the residence time of the freshwater is calculated to relate the filter effi- 
Table 2. The maximum concentrations of $\mathrm{P}$ and $\mathrm{N}\left(\mathrm{mg} \mathrm{L}^{-1}\right)$ in the discharge from sewage treatment plants of different size (person equivalents, pe).

\begin{tabular}{lcc}
\hline $\begin{array}{l}\text { Sewage treatment } \\
\text { facilities (pe) }\end{array}$ & $\begin{array}{c}\mathrm{P} \\
\left(\mathrm{mg} \mathrm{L}^{-1}\right)\end{array}$ & $\begin{array}{c}\mathrm{N} \\
\left(\mathrm{mg} \mathrm{L}^{-1}\right)\end{array}$ \\
\hline$>50000$ & 0.1 & 4 \\
$10000-50000$ & 0.1 & 6 \\
$<10000$ & 0.15 & 10 \\
\hline
\end{tabular}

ciency to physical characteristics of the archipelago as described by Nixon et al. (1996). A freshwater tracer in the model is used to determine the freshwater volume $\left(V_{\mathrm{qf}}\right)$ in the different parts of the archipelago. The freshwater residence time is estimated by the flushing time calculated from the freshwater volume divided by the freshwater discharge received from land $\left(Q_{\mathrm{f}}\right)$ as in the freshwater fraction method discussed by Sheldon and Alber (2006). The filter efficiency was calculated for the inner, the sum of the intermediate and inner archipelago, and the entire Stockholm Archipelago.

\subsubsection{Oxygen reduction scenario}

In the model, denitrification is an $\mathrm{O}_{2}$-dependent process that has a maximum rate at $\mathrm{O}_{2}$ concentration of about $45 \mu \mathrm{mol} \mathrm{L}{ }^{-1}\left(\sim 1 \mathrm{ml} \mathrm{L}^{-1}\right)$, while denitrification halts under anoxic conditions. Also, $\mathrm{P}$ is affected by oxygen since $\mathrm{P}$ has an oxygen-dependent adsorption behaviour on particulate iron(III)oxyhydroxides (Mortimer, 1941). The adsorption of $\mathrm{P}$ on particles can lead to higher burial rates during oxic conditions compared to anoxic conditions when the release rate of $\mathrm{P}$ from the sediment is higher (Viktorsson et al., 2012; Almroth-Rosell et al., 2015). This $\mathrm{O}_{2}$-dependent adsorption behaviour is also simulated by the model (Eilola et al., 2009) using a reduced release of $\mathrm{P}$ from the sediment when $\mathrm{O}_{2}$ is present in the bottom water. The effect of the $\mathrm{O}_{2}$ concentration on the filter efficiency is studied in an experiment where the $\mathrm{O}_{2}$ concentration was reduced in the SCOBI model by a fixed amount, $134 \mu \mathrm{mol} \mathrm{L}^{-1}\left(3 \mathrm{ml} \mathrm{L}^{-1}\right)$, during the simulation period (1990-2012).

\subsubsection{Nutrient load reduction scenario}

The SCM is also used to investigate the effect of a reduction in the nutrient load from land to the Stockholm Archipelago. The reductions are applied to the forcing from 2010 with a river load of $4027 \mathrm{t} \mathrm{N} \mathrm{yr}^{-1}$ and $163 \mathrm{t} \mathrm{Pyr}^{-1}$, and a load from point sources of $1805 \mathrm{t} \mathrm{Nyr}^{-1}$ and $30 \mathrm{tPyr}^{-1}$ to the entire Stockholm Archipelago. Reductions in point sources were estimated from realistic minimum discharge concentrations of $\mathrm{N}$ and $\mathrm{P}$ from sewage treatment facilities based on technical feasibility, but not on economic or resource sustainability (Table 2, Kerstin Rosén Nilsson, County Administrative Board of Stockholm, personal communication, 2015). Point
Table 3. The correlation coefficients $(r)$ between observations (obs) and model results (S-HYPE), and the long-term (1990-2012) averages of river outflow $\left(Q_{\mathrm{F}}\right)$ and nutrient loads from Lake Mälaren.

\begin{tabular}{|c|c|c|c|c|}
\hline Variable & Units & $\begin{array}{r}\text { Average } \\
\text { obs }\end{array}$ & $\begin{array}{l}\text { Average } \\
\text { S-HYPE }\end{array}$ & $r$ \\
\hline$Q_{\mathrm{F}}$ & $10^{6} \mathrm{~m}^{3}$ month $^{-1}$ & 421 & 422 & 0.94 \\
\hline $\mathrm{TN}$ & $\mathrm{tmonth}^{-1}$ & 270 & 271 & 0.93 \\
\hline DIN & $\operatorname{tmonth}^{-1}$ & 83 & 76 & 0.86 \\
\hline $\mathrm{TP}$ & $\mathrm{tmonth}^{-1}$ & 13 & 11 & 0.87 \\
\hline DIP & $\mathrm{t}_{\text {month }}-1$ & 5.7 & 5.7 & 0.79 \\
\hline
\end{tabular}

sources from different industries are assumed to decrease their discharge of $\mathrm{N}$ and $\mathrm{P}$ by $10 \%$. The minimum discharge concentrations, and the $10 \%$ reduction from industries, resulted in reductions by approximately $51 \%$ of $\mathrm{N}$ and $34 \%$ of $\mathrm{P}$ from point sources. The reductions of $\mathrm{N}$ and $\mathrm{P}$ from land runoff, e.g. due to decreased nutrient load from agriculture and increased use of small-sized sewage treatment plants by individual households, are set to $15 \%$ for $\mathrm{N}$ and $10 \%$ for $\mathrm{P}$. The combined reductions in rivers and point sources result in a total decrease in $\mathrm{N}$ and $\mathrm{P}$ load by 20 and $12 \%$ relative to 2010. An SCM spin-up run period of 45 years, with forcing from year 2010, provides the steady-state initial conditions used for the reduction experiment. After the spin-up period the reductions of the nutrient loads are implemented.

\section{Results and discussion}

\subsection{Validation}

The variability of the modelled discharge of water and nutrients by the S-HYPE model agrees well with observations (Fig. 5 and Table 3) for the simulated period (1990-2012). A good description of river runoff is needed because the nutrient loads are strongly related to the magnitude of river outflow $\left(Q_{\mathrm{F}}\right)$ as seen in Fig. 5. The model seems to slightly underestimate the spring discharge and overestimate low-flow regimes relative to observations. However, overall it captures a realistic annual variation in the discharge, which is reflected in high correlation coefficients (Eq. 2) for all evaluated parameters (Table 3). Highest correlation coefficients are found for $Q_{\mathrm{F}}$ and $\mathrm{TN}$, compared to the slightly lower values for TP, DIP and DIN, which is in accordance with previous studies (Grimvall et al., 2014; Strömqvist et al., 2012). An extensive validation is also available in Sahlberg et al. (2008).

Datasets from eight stations (Table 1) fulfilled the requirements of good data availability and were used in the evaluation of the SCM results. There are aspects that are important to have in mind when comparing model results and observations. In the model the state variables are horizontally averaged in each basin, while observations are measured at one station at a certain location. The Stockholm Archipelago 


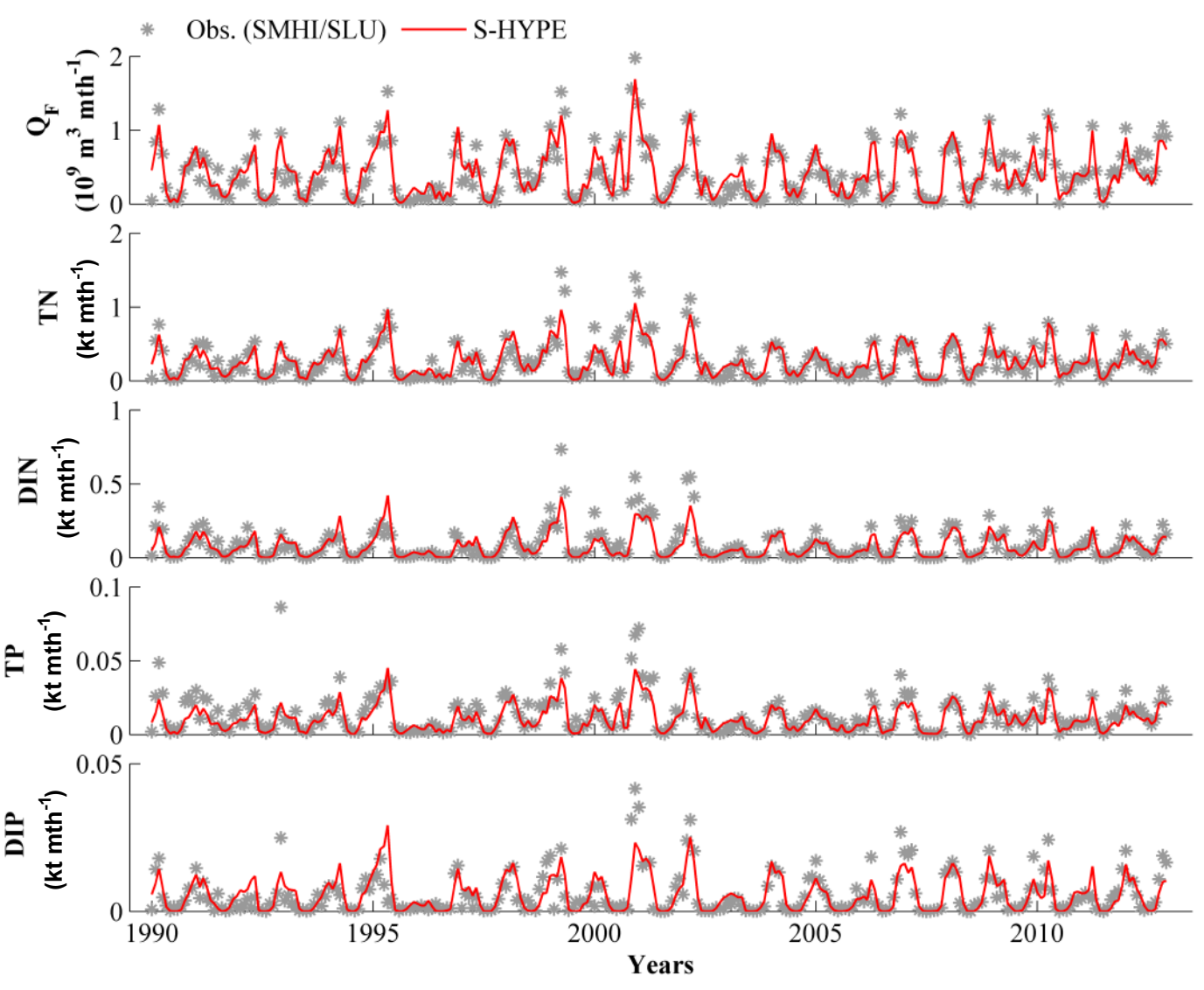

Figure 5. Observed (asterisks) and modelled (line) monthly outflow $\left(Q_{\mathrm{F}}\right)$ and nutrient loads from Lake Mälaren through Norrström to the Strömmen basin for the modelled period (1990-2012). DIN is the sum of nitrate and ammonium.

has relatively large spatial salinity gradients and the representativeness of a station when compared to model results can be somewhat limited if, for example, the position of the station is close to an outlet or inlet of the basin. Observations may in general also be influenced by local conditions, e.g. sewage effluents, high sediment fluxes or stagnant conditions, which are smeared out in the average results of the model. Still, we assume for the present study that the station data are good enough for the quantitative model validation and give a background for discussions about model strengths and weaknesses. As an example, validation results are shown for one of the basins where the number of observations is large enough during both summer and winter periods to be included in the validation process. The example is from station Blockhusudden (position G in Fig. 3), where the largest dataset of observations was found. The station is situated at the boundary between the innermost basin Strömmen and the next adjacent sub-basin.

The objective correlation coefficients (Eq. 2) and the cost function value (Eq. 3) for the different state variables correspondingly implied that the model manages to simulate the average vertical winter and summer profiles with good or acceptable skills in the basin Strömmen (Fig. 6g), except for the average seasonal value of DIN that was described as not good. The differences between model results and observations of DIN may be a result of the location of the monitoring station.

The long-term average summer depth profiles of modelled salinity and oxygen in the basin Strömmen correlate well with observations, while the winter values of salinity were too low, especially in the surface layers (Fig. 7a, b). This difference is partly due to the fact that the salinity of a station at the entrance to the basin more reflects the boundary conditions of the downstream basin than the mean conditions in Strömmen. The surface winter concentrations of oxygen were too high but decreased with depth and became too low in the lower layers (Fig. 7b). It might be expected that winter surface oxygen concentrations in observations should be higher than in summer because of the temperature effect on oxygen saturation concentrations as seen from the model results. However, the number of observations during winter are limited and occurred mostly in November and February, which may influence the average values of the observations.

The results indicate that there is an impact from local conditions at the monitoring station that is not captured by the model setup. The modelled DIN depth profiles show higher 

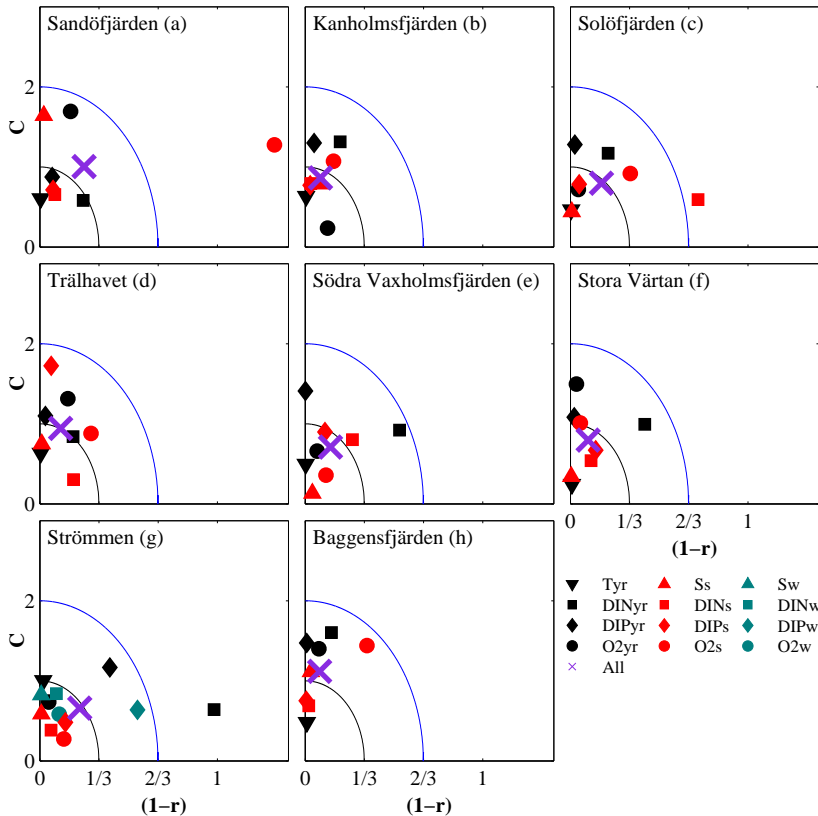

Södra Vaxholmsfjärden (e)
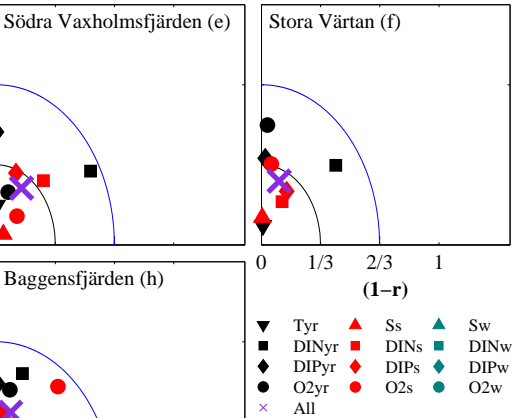

Figure 6. Average cost function $(C)$ and correlation coefficients, adjusted $(1-r)$ to the range $0-1$, for an overview of the model skill at the eight different validation sites (a-g). The individual skills of the different parameters, average seasonal variation (black) and/or the vertical summer (red) and winter (turquoise) profiles of temperature $(T)$, DIN, DIP and oxygen concentrations $\left(\mathrm{O}_{2}\right)$ are shown, as well as the combined model skills for all variables (purple cross). Variables within the inner quarter circle and between the two quarter circles are considered to be good and acceptable, respectively, while variables that are outside the quarter circles are not well simulated.

values at about $15 \mathrm{~m}$ depth during both winter and summer (Fig. 7c), while the DIP profiles values seems to be satisfactory at all depth and periods (Fig. 7d). Also, the individual observations show higher concentrations of both DIN and DIP around $15 \mathrm{~m}$ depth, which is where the halocline has its largest vertical gradient. This depth level corresponds to the depth where two sewage water treatment plants relieve their sewage water in the model. The winter stratification was stronger in the model because of the lower surface salinity. This hampers the vertical transports of oxygen and has an influence on the winter oxygen conditions in the deep water that were lower in the model compared to the observations from the more well ventilated entrance area.

The average seasonal variation in the surface temperature and the bottom water oxygen concentrations was captured by the model, but not the increase in surface nutrients, especially DIN, during autumn (Fig. 8). The surface salinity was overall somewhat low, which is probably a result of the location of the monitoring station, as described above.

In the other basins used in the evaluation (vertical and seasonal profiles are not shown) of the SCM state variables during winter, summer and season were simulated with good or
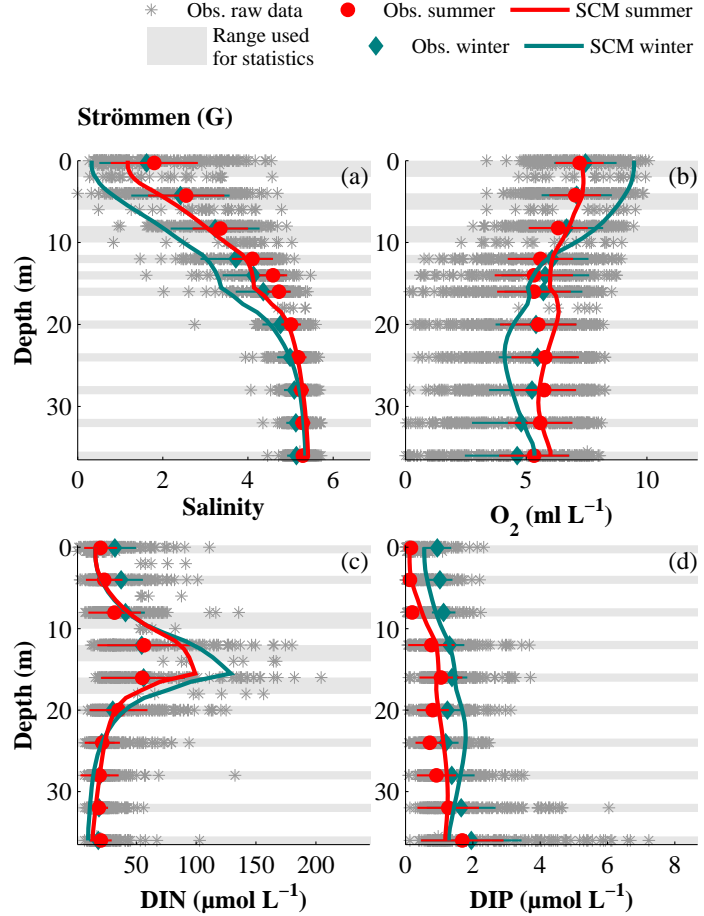

d)

Figure 7. The SCM modelled (lines) and observed (circle and diamond) vertical average profiles (1990-2012) of salinity (a) and concentrations of oxygen $\left(\mathrm{O}_{2} ; \mathbf{b}\right)$, DIN (c) and DIP (d) in the basin Strömmen during winter (turquoise) and summer (red) months. Depth layers with dense number of observations (grey asterisks) determined the vertical depth intervals (grey shaded area) used in the profile calculations. The standard deviations (horizontal lines) were calculated for the summer and winter values of the observations.

acceptable skills, except for the average vertical summer profiles of DIN in the basin Solöfjärden (Fig. 6c) and oxygen concentration in the basin Sandöfjärden (Fig. 6a). The combined model skills, which were calculated as the average of the individual $r$ and $\mathrm{C}$ values, were good in six of the eight evaluated basins (purple cross in Fig. 6). In the remaining two basins the skills were considered acceptable.

\subsection{Retention of nutrients in the Stockholm Archipelago}

The load and the inventories of $\mathrm{N}$ and $\mathrm{P}$ may change and vary between the beginning and the end of a studied period, and thus the determination of total nutrient retention depends on the timescales of consideration as discussed in Sect. 3.2.3. During the period 1990-2012, on average $174 \mathrm{t} \mathrm{P} \mathrm{yr}^{-1}$ and $5846 \mathrm{t} \mathrm{N} \mathrm{yr}^{-1}$ entered the inner archipelago, mainly from Lake Mälaren. These amounts represent a major part of the $217 \mathrm{tP} \mathrm{yr}^{-1}$ and $8288 \mathrm{t} \mathrm{N} \mathrm{yr}^{-1}$ which entered the entire Stockholm Archipelago (Fig. 9). The P load from point sources was clearly lower than the river load (Fig. 10). However, the $\mathrm{N}$ load from point sources was higher than the river load in the beginning of the studied period (Fig. 10b) but 

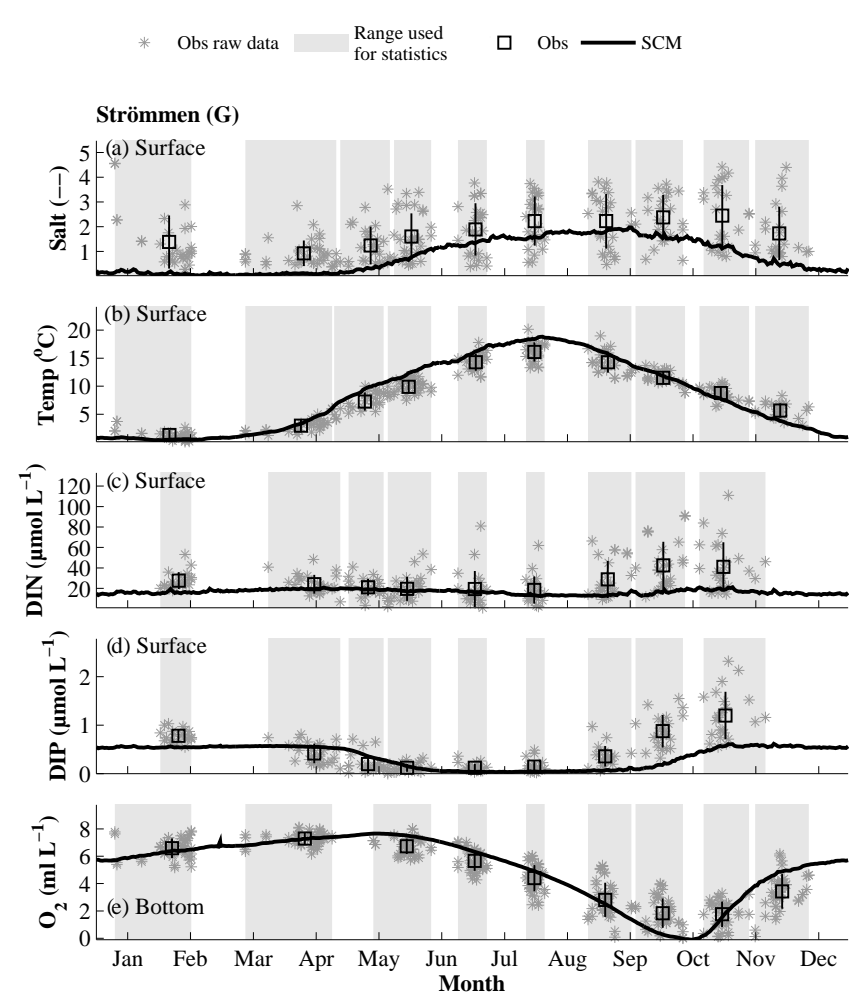

Figure 8. Simulated (lines) and observed averages (squares) of the seasonal variation and the standard deviation (vertical lines) of the observations in the basin Strömmen (1990-2012) of surface temperature (Temp), salinity, DIN and DIP and of the bottom water oxygen concentrations. Time periods with dense number of observations (grey asterisks) determined the time intervals (grey shaded area) used in the calculations.

decreased in the middle of the 1990s due to the implementation of a more effective method to remove $\mathrm{N}$ in the wastewater treatment facilities. The $\mathrm{P}$ supply to the intermediate archipelago mainly originated from runoff from land, while for $\mathrm{N}$ there were also some point sources that contributed to the land load on the same level. In the outer archipelago the nutrient load from land was almost negligible and most of the nutrients were deposited from the atmosphere.

Largest amounts of $\mathrm{P}$ and $\mathrm{N}$ in the model were retained in the outer archipelago compared to the intermediate and inner archipelagos (Fig. 9). The retentions of all supplied $\mathrm{P}$ and N, including the net import from upstream areas, within the inner, intermediate and outer Stockholm archipelagos amounts to 18,23 and $48 \%$ for P, respectively, and 14, 26 and $60 \%$ for $\mathrm{N}$, respectively. The area of the three zones increases from inner $\left(109 \mathrm{~km}^{2}\right)$ to the intermediate $\left(759 \mathrm{~km}^{2}\right)$ and outer archipelago $\left(2360 \mathrm{~km}^{2}\right)$, and thus the retention of nutrients seems to increase with increased area. On the other hand, the average of the area-specific retention of $\mathrm{P}$ and $\mathrm{N}$ was highest in the inner archipelago for the simulation period and decreased towards the open sea (Fig. 11). The permanent retention was relatively stable during the simulated period, while

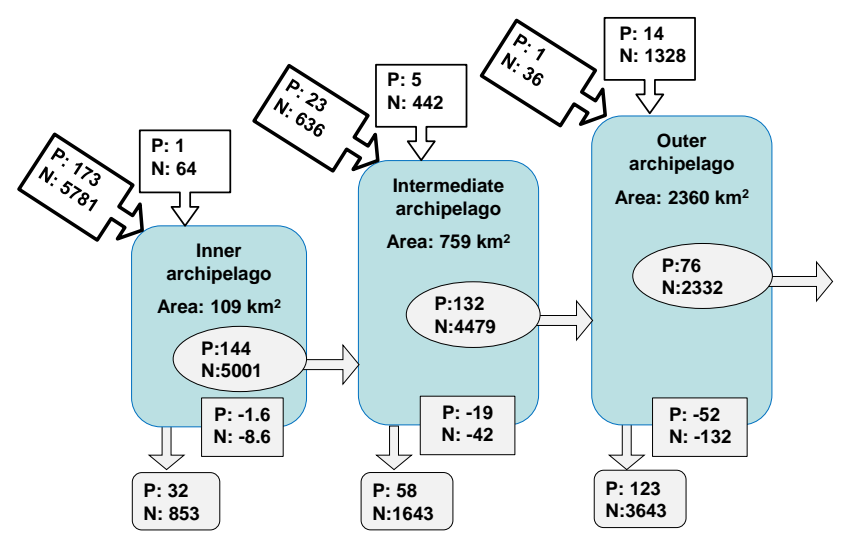

Figure 9. Transport scheme of $\mathrm{N}$ and $\mathrm{P}\left(\mathrm{t} \mathrm{yr}^{-1}\right)$ from land (tilted top boxes) and atmosphere (top boxes), as well as the net exchange from the inner, intermediate and outer archipelago (ellipse) towards the open sea. Total retention is the sum of temporary retention (square) and permanent retention (square with round corners). For P, burial is the only process that leads to permanent retention, while for $\mathrm{N}$ denitrification also removes $\mathrm{N}$. Negative values for the temporary retention mean a decrease in the benthic and/or pelagic pools of nutrients.

fluctuations in the temporal retention reflect the effect of varying riverine nutrient input (Fig. 10c, d). The water depth and the residence time affect the retention of nutrients, which will be further discussed in Sect. 3.2.2. The largest part of the total retention in the entire Stockholm Archipelago was permanent, which for $\mathrm{P}$ means burial. For $\mathrm{N}$, benthic denitrification represented as much as almost $92 \%$ of the permanent retention and burial less than $8 \%$, and pelagic denitrification was below $1 \%$.

Karlsson et al. (2010) found in their empirical study for 1982-2007 that about $15 \%$ of the total input of $\mathrm{N}$ and 10 to $13 \%$ of the total input of $\mathrm{P}$ were retained in the inner Stockholm Archipelago. However, their numbers are based on the total input and thus both the land load and an estimated input from outer areas, i.e. the intermediate Stockholm Archipelago. A recalculation from the given numbers in their study resulted in a filter efficiency of about 25 and $24 \%$ for $\mathrm{N}$ and about 21 and $30 \%$ for $\mathrm{P}$ of the nutrient load from land and atmosphere for the periods 1982-1995 and 1996-2007, respectively. These numbers of the filter efficiency are higher than the numbers in the present model study. To be able to compare the numbers, a recalculation of the filter efficiency in the SCM for the latter period (1996-2007) in the inner archipelago was performed, but this did not change the SCM results considerably. The largest difference between the two studies is caused by the calculation of net exchange of nutrients through the sounds. The transport through the sounds was in Karlsson et al. (2010) calculated from average volume flows estimated from mass balance calculations for salt together with budget calculations using observations of average nutrient concentrations. In the present study the ex- 

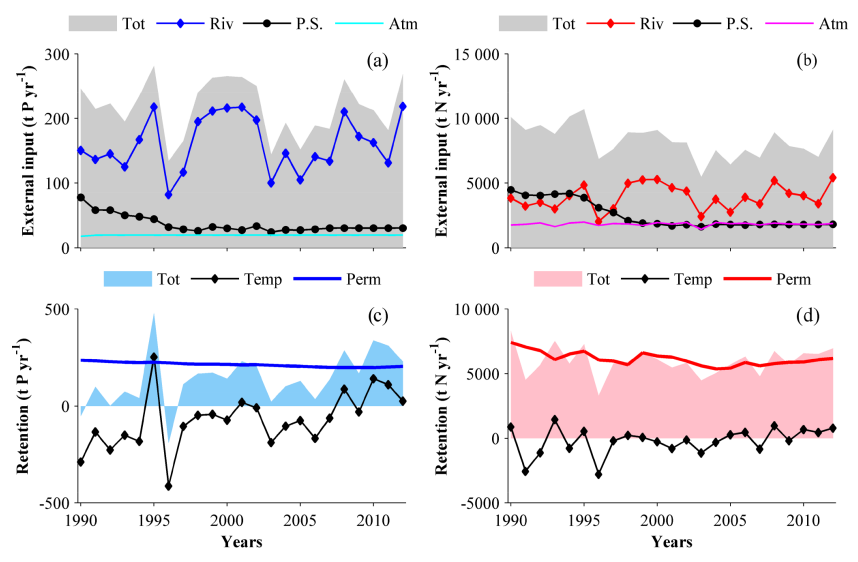

Figure 10. The external annual load and retention $\left(\mathrm{t} \mathrm{yr}^{-1}\right)$ of $\mathrm{P}(\mathbf{a}$, c) and $\mathrm{N}(\mathbf{b}, \mathbf{d})$ in the entire Stockholm Archipelago for the period 1990-2012. Total load (shaded area) and the contributions from the different sources - rivers and land runoff (diamonds), point sources (circles) and atmosphere (solid line) - are shown in the top row. The total retention (shaded area) as a sum of permanent retention (solid line) and temporary retention (diamonds; $\mathbf{c}, \mathbf{d}$ ) is shown in the bottom row.

change of nutrients between the inner and the intermediate archipelago was part of the dynamic model calculations in the SCM. The SCM net outflow from the inner archipelago for $\mathrm{N}$ and $\mathrm{P}$ was about 11 and $8 \%$, respectively, larger compared to the net outflow of the nutrients in the Karlsson et al. (2010) study. Another difference between the two studies was the land load of $\mathrm{P}$, which was about $8 \%$ lower in the SCM. The difference in land load of $\mathrm{N}$ was only about $1 \%$. Thus, calculations from an empirical model based on Knudsen's relations (Knudsen, 1900) and calculations using longterm average values resulted in about $10 \%$ higher retention efficiency values compared to the calculations from SCM, a coupled numeric physical-biogeochemical model with high vertical resolution and a small time step. In spite of the difference in models, the result are surprisingly close.

The average temporary retention in SCM for the entire simulated period is negative in all three parts of the archipelago for both $\mathrm{P}$ and $\mathrm{N}$ (Figs. 9 and 10). The reason for negative temporary retention is mainly a decrease in the benthic nutrient pools during the period (Fig. 12). The largest decrease $(29 \%)$ is found in the pelagic pool of $\mathrm{N}$ in the inner archipelago, which coincides with the decrease in $\mathrm{N}$ load from point sources (Fig. 10). In the intermediate and outer Stockholm archipelagos the pelagic pool of $\mathrm{N}$ remains at about the same level through the whole simulation period. The large decreases in the benthic pools of $\mathrm{N}$ and $\mathrm{P}$ (14$18 \%$ ) occur in the intermediate and outer archipelagos, while there are only small changes in the pelagic and benthic pools of $\mathrm{P}$ in the inner archipelago. Because of the nutrient retention there is a reduced net transport of $\mathrm{N}$ and $\mathrm{P}$ from the inner archipelago towards the intermediate and outer archipela-
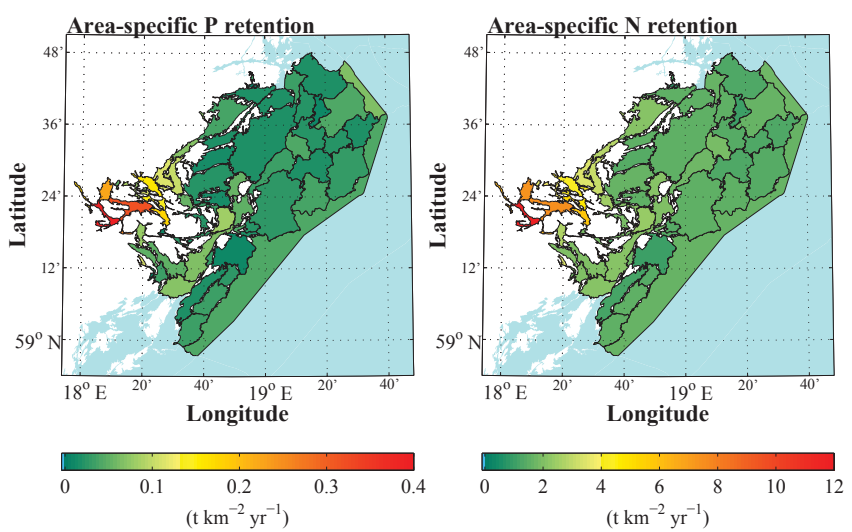

Figure 11. The retention per area unit $\left(\mathrm{t} \mathrm{km}^{-2} \mathrm{yr}^{-1}\right)$ of $\mathrm{P}(\mathrm{left})$ and $\mathrm{N}$ (right) in each basin of the Stockholm Archipelago.

gos and further to the open sea during the simulated period (Fig. 9). The annual temporary retention of $\mathrm{P}$ in the entire Stockholm Archipelago increases with time during the simulated period (Fig. 10). There is a change to positive values at the end of the period, when there again is a build-up of the benthic pools of $\mathrm{P}$ (Fig. 12). The build-up is most likely a result of better oxygen conditions in the modelled deep water (not shown) during the end of the simulation period, which lead to a lower release of $\mathrm{P}$ from the sediment to the water column (Eilola et al., 2009). For the temporary retention of $\mathrm{N}$ there is no visible trend in the variation with time. In addition to the nutrient load from land and the net export of nutrients to outer areas, there is also an extensive circulation of nutrients between the coast and the open sea. The importance of imported nutrients into the coastal zones from sea have been discussed in earlier studies (e.g. Humborg et al., 2003) in which it was concluded that many estuaries has a net import of DIN and DIP from sea, e.g. Chesapeake Bay (Boynton et al., 1995). This is also shown for, for instance, the Mid-Atlantic Bight, where almost 3 times the riverine input of $\mathrm{N}$ is denitrified (Fennel et al., 2006). In different parts of the shelf in the Gulf of Mexico the denitrified proportion of the land input of $\mathrm{N}$ is in total $86 \%$, where locally on the different part of the shelves the denitrification fraction of the supply from land varied between 68 and $341 \%$ (Xue et al., 2013). Thus, in many cases the import is larger than the export and the coastal zones works as a filter not only for the nutrients from land but also for the nutrients from the open sea, as also discussed in Sect. 3.2.3.

\subsection{The coastal filter}

From the present results it can be concluded that the Stockholm Archipelago works like a filter for nutrients that enter the coastal zone from land and atmosphere. However, a rather large area of the archipelago is needed to effectively retain the nutrients. About 82 and $86 \%$ of $\mathrm{P}$ and $\mathrm{N}$ supplies, respectively, pass the small inner archipelago and are exported 

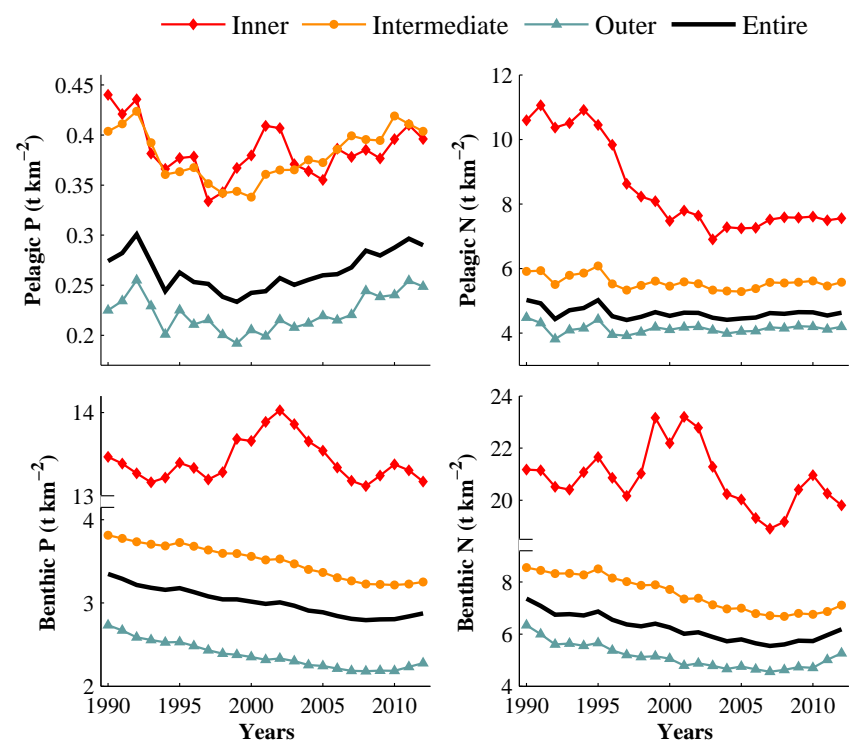

Figure 12. The total content $\left(\mathrm{g} \mathrm{m}^{-2}\right)$ of the pelagic (top) and benthic (bottom) P (left) and N (right) in the inner (diamonds), intermediate (circles), outer (triangles) and entire (black line) Stockholm archipelagos.

to the intermediate archipelago. In the intermediate and the outer archipelago all local supplies of nutrients from land and atmosphere are retained together with a fraction of the nutrients imported from the inner archipelago. The filter efficiencies increase with increased coastal area from land to the sea continuum (Fig. 13). However, the filter efficiency of the entire Stockholm Archipelago is not effective enough to retain of all the nutrients that enter the system from land and the atmosphere, but still at least 65 and $72 \%$ of the supplied $\mathrm{P}$ and $\mathrm{N}$, respectively, are retained. The total retention numbers (permanent and temporary) correspond to $141 \mathrm{tP} \mathrm{yr}^{-1}$ and $5954 \mathrm{t} \mathrm{N} \mathrm{yr}^{-1}$ (Fig. 9). Since Stockholm Archipelago is the largest archipelago in Sweden, it might be that most of the other Swedish coastal areas with a large runoff from land would be less effective as coastal filters and thus contribute to a larger extent to the eutrophication in the open sea. This is one question in focus of an ongoing study where the entire Swedish coastal area will be evaluated similarly to the present study.

\subsection{Processes affecting retention}

The present study was performed in an area characterized as an eutrophic archipelago in an inland sea with basins having oxic, hypoxic and anoxic bottom waters. Nixon et al. (1996) showed that the retention of $\mathrm{P}$ and $\mathrm{N}$ correlated to the $\log$ scale of the ratio between the average depth and the residence time of the study areas, which is confirmed by the results from the studies by Billen et al. (2011), Hayn et al. (2014) and Nielsen et al. (2001) as well as by the present study (Fig. 13). The freshwater residence time in the Stockholm
Archipelago is 48 days in the inner, 108 days in the middle and inner, and 185 days in the entire area. No clear relationship was found between the filter efficiency and the average depth, which vary between 17 and $20 \mathrm{~m}$ for the three areas. These results are in agreement with Nixon et al. (1996), who showed that including the depth in the analysis of retention vs. residence time did not much improve their regression. In the present study the change in the filter efficiency with residence time is about $0.5-0.6 \%$ per day. The results of the present retention estimates are in agreement with results from previous studies (Billen et al., 2011; Hayn et al., 2014; Nielsen et al., 2001; Nixon et al., 1996), but with somewhat higher values in the entire archipelago (Fig. 13). Their studies were performed in various types of systems: coastal lagoons, drowned river estuaries, coastal embayments, and inland seas in North America and in Europe. Those systems varied from being relatively pristine to systems with large point sources (eutrophic), and they also varied between oxic and hypoxic and/or anoxic conditions. In shallow areas larger parts of the sinking particulate organic material may reach all the way down to the seafloor, where it can be exposed to retention processes such as burial and denitrification. On the other hand, in a much deeper area a larger part of the organic material may become remineralized within the water column on its way down to the seafloor. The nutrients can then be reused by phytoplankton and/or be further transported out from the system. Long residence times in a system increase the time of exposure for biogeochemical transformation processes and sedimentation within the system and larger parts of the nutrients may be retained.

Denitrification increases the retention in areas with longer residence times (Nixon et al., 1996; Finlay et al., 2013) as also seen from Fig. 13. In the Randers Fjord the residence time was short ( 6 days) and the filter efficiencies of $\mathrm{N}$ and $\mathrm{P}$ were lower, 10 and $9 \%$, respectively (Nielsen et al., 2001), compared to the Stockholm Archipelago, where the freshwater residence time is longer. The denitrified proportion of the permanently retained $\mathrm{N}$ was also lower, about $60 \% \mathrm{com}$ pared to in the Stockholm Archipelago (92\%). Oxygen is an important factor regulating the magnitude of denitrification. In waters with longer residence time, the bottom water might be less ventilated, and thus the bottom water oxygen concentrations might be lower with higher denitrification as a result. As a result of the forced reduction in the oxygen concentrations with $134 \mu \mathrm{M}$ the hypoxic areas increased by $49 \mathrm{~km}^{2}$ $(300 \%)$ and the anoxic area increased by $13 \mathrm{~km}^{2}(360 \%)$ in the entire Stockholm Archipelago. The reduced oxygen concentration led to increased $\mathrm{N}$ retention $\left(780 \mathrm{t} \mathrm{yr}^{-1}\right.$ or $\left.14 \%\right)$ due to increased denitrification and decreased $\mathrm{P}$ retention $\left(49 \mathrm{tyr}^{-1}\right.$ or $\left.28 \%\right)$ as a result of higher release of $\mathrm{P}$ from the sediment. Denitrification increased the fraction of permanent retention from 92 to $94 \%$, while the buried fraction decreased. The inner archipelago had the largest increase in hypoxic and anoxic areas and also the largest changes in reten- 

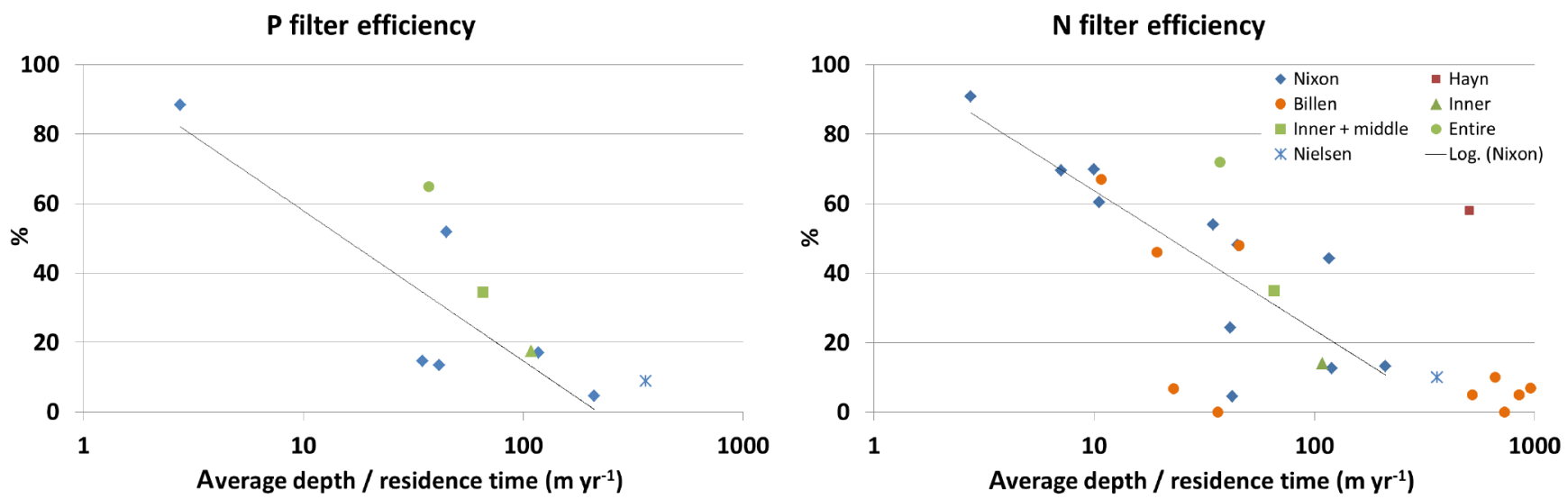

Figure 13. The filter efficiency of $\mathrm{P}$ (left) and $\mathrm{N}$ (right) vs. the logarithmic ratio between the average depth and the freshwater residence time of the study areas (month $\mathrm{yr}^{-1}$ ). Data from other studies are from Billen et al. (2011), Hayn et al. (2014), Nielsen et al. (2001) and Nixon et al. (1996). The straight line shows the logarithmic regression for the data from Nixon et al. (1996).

tion of $\mathrm{N}$ and $\mathrm{P}$. The $\mathrm{N}$ retention increased there by $243 \mathrm{t} \mathrm{yr}^{-1}$ (29\%) and the P retention decreased by $9 \operatorname{tyr}^{-1}(38 \%)$.

Benthic primary producers and benthic fauna are also important for the retention of nutrients in shallow coastal ecosystems (McGlathery et al., 2007; Norkko et al., 2012). Assimilation of nutrients during primary production does not directly change the inventory of $\mathrm{N}$ and $\mathrm{P}$ but rather transfers the nutrients into organic material. Plant uptake at the bottom can, for example, lead to increased burial and also influence on the oxygen-dependent biogeochemical processes in the sediment due the plant metabolism (McGlathery et al., 2007). These processes are not yet implemented in the SCM, which only includes pelagic primary production, and therefore are the influences by bottom living plants included in the present study. Including these processes may have some impact on the model dynamics, for example on bottoms where seagrasses and burrowing macrofauna might influence the decomposition of organic material and the permanent burial of nutrients and organic matter. The evaluation of forcing and model results indicates, however, that the model system is able to reproduce much of the observed physics and nutrient dynamics in the archipelago, which gives confidence to the budget estimations of nutrient retention in the area. A quantitative evaluation of the effect and the implementation of benthic flora and fauna to the model is therefore left for future work.

It is also important to know whether a system is in balance with the nutrient loads or not since it would affect the retention capacity. In this study the temporary retention is negative for both $\mathrm{N}$ and $\mathrm{P}$ in all three areas of the Stockholm Archipelago, which implies that the system is not in a steady state. This imbalance is, however, expected since there are reductions of the nutrient loads in the first part of the simulation period (Fig. 10a, b). However, the possibility that the results may be influenced by unknown initial conditions of sediment concentrations should not be excluded. There are

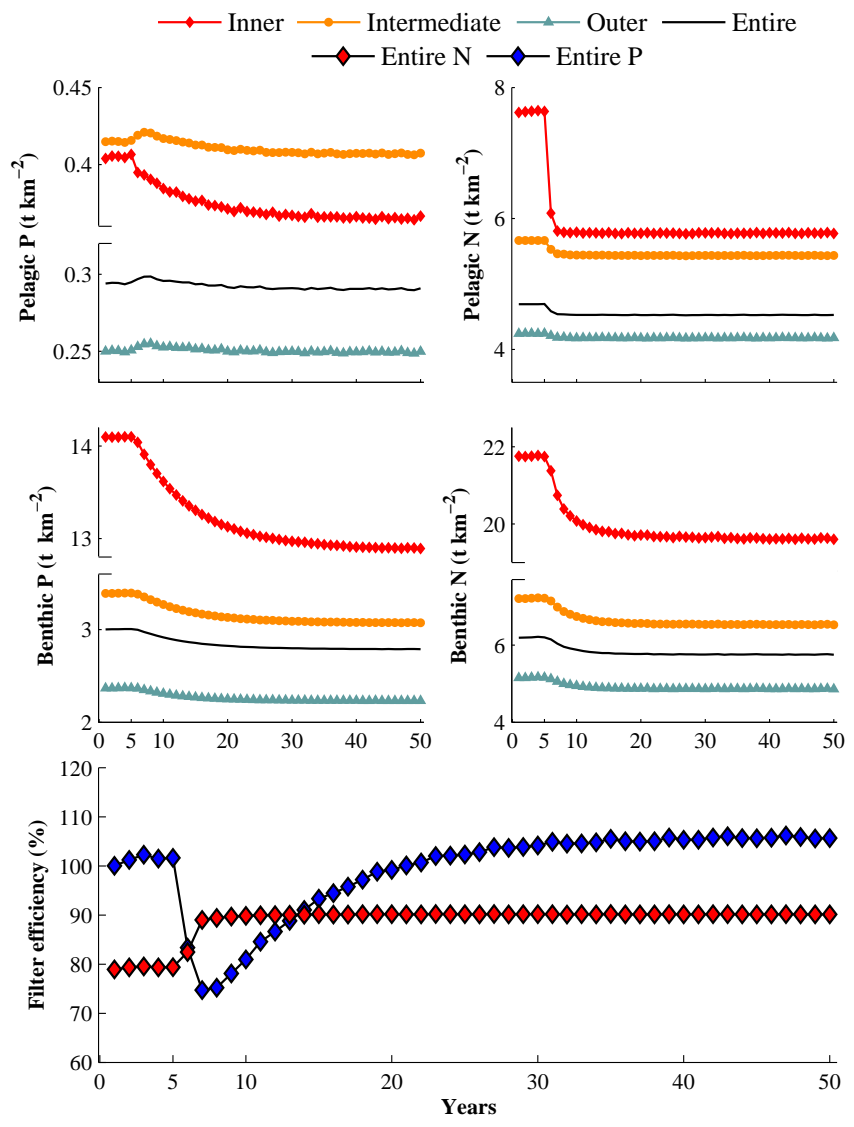

Figure 14. Pelagic (upper) and benthic (middle) pools of $\mathrm{P}$ (left) and $\mathrm{N}$ (right) in the inner (red), intermediate (orange), outer (turquoise) and entire (black) Stockholm Archipelago. The filter efficiencies (\%) of $\mathrm{N}$ (red) and $\mathrm{P}$ (blue) load from land and atmosphere are shown for the entire Stockholm Archipelago (lower), where the small peaks derive from leap years. 
Table 4. The total land load (rivers, land runoff and atmosphere) of $\mathrm{P}$ and $\mathrm{N}\left(\mathrm{t} \mathrm{yr}^{-1}\right)$ to the Stockholm Archipelago, the size of the benthic and pelagic $\mathrm{N}$ and $\mathrm{P}$ pools $(t)$, the export from the area $\left(\mathrm{t} \mathrm{yr}^{-1}\right)$ and the filter efficiency $\left(F_{\text {eff }}\right)$ before and after the nutrient reductions, as well as their percentage changes. The system is in steady state in both cases; thus, the benthic and pelagic pools are in balance with the nutrient load.

\begin{tabular}{lllrrr}
\hline & & Unit & $\begin{array}{r}\text { Initial } \\
\text { values }\end{array}$ & $\begin{array}{r}\text { End of } \\
\text { period }\end{array}$ & $\begin{array}{r}\text { Change } \\
(\%)\end{array}$ \\
\hline $\mathrm{P}$ & Total load & $\mathrm{t} \mathrm{yr}^{-1}$ & 213 & 186 & -13 \\
& Pool $^{1}$ & $t$ & 10661 & 9952 & -7 \\
& Export & $\mathrm{t} \mathrm{yr}^{-1}$ & -3.5 & -11 & -207 \\
& $F_{\text {eff }}$ & $\%$ & 101 & 106 & \\
\hline $\mathrm{N}$ & Total load & $\mathrm{t} \mathrm{yr}^{-1}$ & 7690 & 6164 & -20 \\
& Pool & $t$ & 35196 & 33216 & -6 \\
& Export & $\mathrm{t} \mathrm{yr}^{1}$ & 1585 & 609 & -62 \\
& $F_{\text {eff }}$ & $\%$ & 79 & 90 & \\
\hline \multirow{2}{*}{$\mathrm{N}: \mathrm{P}^{2}$} & Molar ratio & & 42 & 35 & -16 \\
\hline
\end{tabular}

${ }^{1}$ The sum of benthic and pelagic pools. ${ }^{2}$ In the inner archipelago.

only few observations available, and the knowledge about the amount of sediment nutrients involved in biogeochemical cycles is poor.

\subsection{Response to nutrient load reduction}

The fastest response in the nutrient load reduction experiment is seen in the pelagic pool of $\mathrm{N}$ which rapidly decreases, but reaches a steady state after about 3 years with reduced loads (Fig. 14). The pelagic pool of $\mathrm{P}$ decreases in the inner archipelago but increases slightly in the outer areas. The changes in $\mathrm{P}$ pools are slower compared to those in $\mathrm{N}$ pools. The large and fast decrease in pelagic $\mathrm{N}$ in the inner archipelago results in a decreased $\mathrm{N}: \mathrm{P}$ ratio (Table 4), as well as (not shown) lower chlorophyll concentrations, reduced sedimentation, and increased export of $\mathrm{P}$ from the inner archipelago to the outer areas and the Baltic proper. The anoxic areas also decrease by about $30 \%$ as a result of the lower deposition of organic material on the seafloor (not shown). The changes in the benthic pools of $\mathrm{N}$ and $\mathrm{P}$ occur over a longer time period, and the benthic $\mathrm{P}$ pool does not reach a steady state until about 40 years after the reduction.

In the reduction scenario the transport of $\mathrm{N}$ to the open sea from the Stockholm Archipelago decreases by $62 \%$ within four years (Table 4). The filter efficiency of $\mathrm{N}$ in the entire archipelago increases at the same time from 79 to $90 \%$ as a result of the load reduction. The longer response time of $\mathrm{P}$ compared to $\mathrm{N}$ is also observed in the filter efficiency (Fig. 14).

The filter efficiency of $\mathrm{P}$ at the end of the spin-up run is about $100 \%$. This implies that, under the 2010 conditions, all of the P land load is retained in the Stockholm Archipelago when the system is in steady state. This is not the case when the original model forcing is used, which implies that the Stockholm Archipelago is still adjusting to the load reductions already implemented. Thus, under present conditions, the coastal region might continue to improve without further actions.

The filter efficiency of $\mathrm{P}$ decreases to $74 \%$ during the first years after the reduction, coinciding with the large decrease in the $\mathrm{N}$ pelagic pool and the decrease in $\mathrm{N} / \mathrm{P}$ ratio. After the initial decrease, the filter efficiency slowly increases to $106 \%$ at the end of the simulation period - i.e. retention is larger than the land and atmospheric load of P. As a consequence, the export of $\mathrm{P}$ from the archipelago to the Baltic proper decreases with time, and about 18 years after the load reduction the direction of the transport changes. This coincides with the time when the filter efficiency again reached $100 \%$. Thereafter, the archipelago begins to import P from the open sea. Thus, with the contemporary boundary conditions used at the open sea, P from the Baltic proper is retained within the archipelago. For coastal management this indicates the importance of the open sea nutrient conditions when effects of load reductions are evaluated.

These results indicate that local nutrient load abatements can improve the environmental state of a semi-enclosed coastal site (the inner archipelago) that is locally impacted by humans. The results also imply that, for the first 5-15 years, increased nutrient concentrations might be expected locally. However, this effect largely depends on the water residence time and on which nutrient limits the seasonal phytoplankton production initially. However, for the more open coastal zone, represented in the present study by the intermediate and outer archipelago, the response to further nutrient load reductions was minor. This shows that, for open coastal areas, the interactions between the open sea and the coastal zone are probably more important than the land-sea connection.

The present study can conclude that even the eutrophicated Stockholm Archipelago can, after further nutrient load abatements, act as a sink for open-water phosphorus. Similar behaviour was found in Chesapeake Bay (Boynton et al., 1995), which acts as a sink for the total load of $\mathrm{P}$ and thus $\mathrm{P}$ from land, atmosphere and from the open sea.

\section{Conclusions}

Archipelagos are complex areas with many basins and several shallow sounds, which affect the transport of water and the dissolved and particulate nutrients. For the first time, the SCM was used to study the capacity of the coastal filter of nutrients. An evaluation showed that, overall, model results agree with observations.

We focused our study in the northern Baltic proper and investigated retention of $\mathrm{N}$ and $\mathrm{P}$ in the Stockholm Archipelago. The main findings are described below. 
The coastal zone works as an efficient filter for the land loads of nutrients. Under prevailing conditions the total retention are 65 and $72 \%$ of $\mathrm{P}$ and $\mathrm{N}$, respectively, supplied from land.

A sensitivity experiment reducing the land load of nutrients showed that the retention capacity of $\mathrm{N}$ and $\mathrm{P}$ increased. In this case the export of $\mathrm{N}$ from the archipelago decreased and $\mathrm{P}$ was imported from the open sea.

The average filter efficiency is dependent on the spatial dimensions of the coastal area. Thus, nutrient retention per area is largest in the inner archipelago and decreases towards the open sea.

Average water depth and water residence time regulate the retention of nutrients that occur mostly in the sediment due to processes such as burial and denitrification.

The pools of nutrients in the water and in the sediment change with nutrient loads on different timescales and affect the temporal nutrient retention in the area. $\mathrm{N}$ has a rather short response time of about 3 years, while it takes about 40 years for $\mathrm{P}$ to reach balance in a system with constant forcing. Changing $\mathrm{N}: \mathrm{P}$ ratios in the archipelago due to the different response timescales also have an impact on the nutrient retention capacity on decadal timescales.

Coastal management needs to take the aspects of time and balance between nutrient loads and pools into account in the assessment of impacts from nutrient load abatements. On shorter timescales the retention capacity of $\mathrm{P}$ might be less effective when the nutrient load from land decreases.

\section{Data availability}

The model data on which the results in the present study are based on are stored and available from the Swedish Meteorological and Hydrological Institute. Please send your request to ocean.data@smhi.se. Monitoring data can be extracted from the SHARK database at http://www.smhi.se/klimatdata/oceanografi/havsmiljodata/ marina-miljoovervakningsdata.

\section{The Supplement related to this article is available online at doi:10.5194/bg-13-5753-2016-supplement.}

Acknowledgements. The research presented in this study is part of the Baltic Earth programme (Earth System Science for the Baltic Sea region; see http://www.baltex-research.eu/balticearth) and is part of the BONUS COCOA (Nutrient COcktails in COAstal zones of the Baltic Sea) project, which has received funding from BONUS, the joint Baltic Sea research and development programme (Art 185), funded jointly by the European Union's Seventh Framework Programme for research, technological development and demonstration and by the Swedish Research Council for Environment, Agricultural Sciences and Spatial Planning
(FORMAS), grant no. 2013-2056. Additional funding came from the EU Water Framework Directive programme at the Swedish Meteorological and Hydrological Institute. We would like to thank Kerstin Rosén Nilsson at the County Administrative Board of Stockholm for interesting discussions and good advice. We are also grateful to the reviewers and the editor for their good comments and suggestions for improving earlier versions of the manuscript.

Edited by: K. Fennel

Reviewed by: two anonymous referees

\section{References}

Ahlgren, I., Frisk, T., and Kamp-Nielsen, L.: Empirical and theoretical models of phosphorus loading, retention and concentration vs. lake trophic state, in: Phosphorus in Freshwater Ecosystems, Springer, 1988.

Almroth-Rosell, E., Eilola, K., Hordoir, R., Meier, H. E. M., and Hall, P. O. J.: Transport of fresh and resuspended particulate organic material in the Baltic Sea - a model study, J. Marine. Syst., 87, 1-12, 2011.

Almroth-Rosell, E., Eilola, K., Kuznetsov, I., Hall, P. O. J., and Meier, H. E. M.: A new approach to model oxygen dependent benthic phosphate fluxes in the Baltic Sea, J. Marine. Syst., 144, 127-141, 2015.

Areskoug, H.: Nedfall av kväve och fosfor till Sverige, Östersjön och Västerhavet, Rapport 4148, 1993.

Balls, P. W.: Nutrient Inputs to Estuaries from Nine Scottish East Coast Rivers; Influence of Estuarine Processes on Inputs to the North Sea, Estuar. Coast Shelf S, 39, 329-352, 1994.

BED: Baltic Environmental Database, http://www.balticnest.org/ bed, last acess: 31 October 2015.

Bergström, S., Alexandersson, H., Carlsson, B., Josefsson, W., Karlsson, K.-G., and Westring, G.: Climate and Hydrology of the Baltic Sea, in: Ecolocigal Studies, A System Analysis of the Baltic Sea, edited by: Wulff, F., Rahm, L., and Larsson, P., Springer-Verlag, Berlin-Heidelberg, 2001.

Billen, G., Silvestre, M., Grizzetti, B., Leip, A., Garnier, J., Voss, M., Howarth, R., Bouraoui, F., Lepistö, A., and Kortelainen, P.: Nitrogen flows from European regional watersheds to coastal marine waters, European nitrogen assessment, 271-297, 2011.

Bolin, B. and Rodhe, H.: A note on the concepts of age distribution and transit time in natural reservoirs, Tellus, 25, 58-62, 1973.

Boynton, W., Garber, J., Summers, R., and Kemp, W.: Inputs, transformations, and transport of nitrogen and phosphorus in Chesapeake Bay and selected tributaries, Estuaries, 18, 285-314, 1995.

Brattberg, G.: Decreased phosphorus loading changes phytoplankton composition and biomass in the Stockholm archipelago, Vatten, 42, 1-153, 1986.

Carstensen, J., Conley, D., Bonsdorff, E., Gustafsson, B., Hietanen, S., Janas, U., Jilbert, T., Maximov, A., Norkko, A., Norkko, J., Reed, D., Slomp, C., Timmermann, K., and Voss, M.: Hypoxia in the Baltic Sea: Biogeochemical Cycles, Benthic Fauna, and Management, AMBIO, 43, 26-36, 2014.

Conley, D., Bjorck, S., Bonsdorff, E., Carstensen, J., Destouni, G., and Gustafsson, B.: Hypoxia-Related Processes in the Baltic Sea, Environ. Sci. Technol., 43, 3412-3420, 2009. 
Diaz, R. J. and Rosenberg, R.: Spreading dead zones and consequences for marine ecosystems, Science, 321, 926-929, 2008.

Duarte, C. M. and Cebrián, J.: The fate of marine autotrophic production, Limnol. Oceanogr., 41, 1758-1766, 1996.

Edman, M. and Omstedt, A.: Modeling the dissolved $\mathrm{CO}_{2}$ system in the redox environment of the Baltic Sea, Limnol. Oceanogr., 58, 74-92, 2013.

Edman, M. K. and Anderson, L. G.: Effect on $p \mathrm{CO}_{2}$ by phytoplankton uptake of dissolved organic nutrients in the Central and Northern Baltic Sea, a model study, J. Marine. Syst., 139, 166182,2014

Eilola, K., Meier, M. H. E., and Almroth, E.: On the dynamics of oxygen, phosphorus and cyanobacteria in the Baltic Sea; A model study, J. Marine. Syst., 75, 163-184, 2009.

Eilola, K., Gustafsson, B. G., Kuznetsov, I., Meier, H. E. M., Neumann, T., and Savchuk, O. P.: Evaluation of biogeochemical cycles in an ensemble of three state-of-the-art numerical models of the Baltic Sea, J. Marine. Syst., 88, 267-284, 2011.

Eilola, K., Almroth-Rosell, E., and Meier, H. E. M.: Impact of saltwater inflows on phosphorus cycling and eutrophication in the Baltic Sea. A 3D model study, Tellus A, 66, 23985, doi:10.3402/tellusa.v66.23985, 2014.

Finlay, J. C., Small, G. E., and Sterner, R. W.: Human influences on nitrogen removal in lakes, Science, 342, 247-250, 2013.

Fennel, K., Wilkin, J., Levin, J., Moisan, J., O'Reilly, J., and Haidvogel, D.: Nitrogen cycling in the Mid Atlantic Bight and implications for the North Atlantic nitrogen budget: Results from a three-dimensional model, Global Biogeochem. Cy., 20, GB3007, doi:10.1029/2005GB002456, 2006.

Fonselius, S. H.: Hydrography of the Baltic deep basins III, 1969.

Galloway, J. N., Townsend, A. R., Erisman, J. W., Bekunda, M., Cai, Z., Freney, J. R., Martinelli, L. A., Seitzinger, S. P., and Sutton, M. A.: Transformation of the nitrogen cycle: recent trends, questions, and potential solutions, Science, 320, 889-892, 2008.

Grimvall, A., von Brömssen, C., and Lindström, G.: Using processbased models to filter out natural variability in observed concentrations of nitrogen and phosphorus in river water, Environ. Monit. Assess., 186, 5135-5152, 2014.

Gustafsson, B., Schenk, F., Blenckner, T., Eilola, K., Meier, H. E. M., Müller-Karulis, B., Neumann, T., Ruoho-Airola, T., Savchuk, O., and Zorita, E.: Reconstructing the Development of Baltic Sea Eutrophication 1850-2006, AMBIO, 41, 534-548, 2012.

Hansson, M. and Andersson, L.: Oxygen Survey in the Baltic Sea 2013 - Extent of Anoxia and Hypoxia, 1960-2013, Swedish Meteorological and Hydrological Institute, Norrköping, Sweden, Report Oceanography, 50, 22 pp., 2014.

$\mathrm{HaV}$ : Havs och Vattenmyndighetens föreskrifter om klassificering och miljökvalitetsnormer avseende ytvatten, HVMFS 2013, 19, 2013.

Hayn, M., Howarth, R., Marino, R., Ganju, N., Berg, P., Foreman, K. H., Giblin, A. E., and McGlathery, K.: Exchange of nitrogen and phosphorus between a shallow lagoon and coastal waters, Estuar. Coast., 37, 63-73, 2014.

Hejzlar, J., Anthony, S., Arheimer, B., Behrendt, H., Bouraoui, F., Grizzetti, B., Groenendijk, P., Jeuken, M., Johnsson, H., and Porto, A. L.: Nitrogen and phosphorus retention in surface waters: an inter-comparison of predictions by catchment models of different complexity, J. Environ. Monitor., 11, 584-593, 2009.
HELCOM: Ecosystem Health of the Baltic Sea 2003-2007: HELCOM Initial Holistic Assessment., 2010.

Humborg, C., Danielsson, Å., Sjöberg, B., and Green, M.: Nutrient land-sea fluxes in oligothrophic and pristine estuaries of the Gulf of Bothnia, Baltic Sea, Estuar. Coast. Shelf. S., 56, 781793, 2003.

Johnston, C. A.: Sediment and nutrient retention by freshwater wetlands: effects on surface water quality, Crit. Rev. Env. Sci. Tec., 21, 491-565, 1991.

Jonsson, P., Persson, J., and Holmberg, P.: Skärgårdens bottnar, Naturvårdsverket rapport, 5212, 2003.

Karlsson, O. M., Jonsson, P. O., Lindgren, D., Malmaeus, J. M., and Stehn, A.: Indications of recovery from hypoxia in the inner Stockholm archipelago, Ambio, 39, 486-495, 2010.

Kemp, W. M., Testa, J. M., Conley, D. J., Gilbert, D., and Hagy, J. D.: Temporal responses of coastal hypoxia to nutrient loading and physical controls, Biogeosciences, 6, 2985-3008, doi:10.5194/bg-6-2985-2009, 2009.

Knudsen, M.: Ein hydrographischer lehrsatz, Annalen der Hydrographie und Maritimen Meteorologie, 28, 316-320, 1900.

Lännergren, C.: Undersökningar i Östra Mälaren till och med 2009, Stockholm Vatten, 2010.

Lännergren, C., Eriksson, B., and Stehn, A.: Surveys in the Stockholm archipelago 2008, Stockholm Vatten Report, Diary, No: 09SV139, 243, 2009.

Lindh, G.: Miljörapport 2013, Stockholm Vatten VA AB, Stockholm Vatten, 2013.

Lindström, G., Pers, C., Rosberg, J., Strömqvist, J., and Arheimer, B.: Development and testing of the HYPE (Hydrological Predictions for the Environment) water quality model for different spatial scales, Hydrol. Res., 41, 295-319, 2010.

Lücke, J.: Stockholms recipienter, Påverkan av Stockholms framtida avloppsrening, Stockholm Vatten AB, 2014.

Lücke, J.: Undersökningar i Stockholms skärgård 2014, Vattenkemi och växtplankton, och bottenfauna, Stockholm Vatten AB, 2015.

Marmefelt, E., Arheimer, B., and Langner, J.: An integrated biochemical model system for the Baltic Sea, Hydrobiologia, 393, 45-56, 1999.

McGlathery, K. J., Sundbäck, K., and Anderson, I. C.: Eutrophication in shallow coastal bays and lagoons: the role of plants in the coastal filter, Mar. Ecol-Prog. Ser., 348, 1-18, 2007.

Meier, H. E. M., Müller-Karulis, B., Andersson, H., Dieterich, C., Eilola, K., Gustafsson, B., Höglund, A., Hordoir, R., Kuznetsov, I., Neumann, T., Ranjbar, Z., Savchuk, O., and Schimanke, S.: Impact of Climate Change on Ecological Quality Indicators and Biogeochemical Fluxes in the Baltic Sea: A Multi-Model Ensemble Study, AMBIO, 41, 558-573, 2012.

Meier, M., Eilola, K., and Almroth, E.: Climate-related changes in marine ecosystems simulated with a 3-dimensional coupled physical-biogeochemical model of the Baltic Sea, Clim. Res., 48, 31-55, 2011.

Mortimer, C. H.: The Exchange of Dissolved Substances Between Mud and Water in Lakes, J. Ecol., 29, 280-329, 1941.

Naturvårdsverket: Status, potential och kvalitetskrav för sjöar, vattendrag, kustvatten och vatten i övergångszon, En handbok om hur kvalitetskrav i ytvattenförekomster kan bestämmas och följas upp, 2007.

Nielsen, K., Risgaard-Petersen, N., Sømod, B., Rysgaard, S., and Berg $\varnothing$, T.: Nitrogen and phosphorus retention estimated indepen- 
dently by flux measurements and dynamic modelling in the estuary, Randers Fjord, Denmark, Mar. Ecol-Prog. Ser., 219, 25-40, 2001.

Nixon, S. W., Ammerman, J. W., Atkinson, L. P., Berounsky, V. M., Billen, G., Boicourt, W. C., Boynton, W. R., Church, T. M., Ditoro, D. M., Elmgren, R., Garber, J. H., Giblin, A. E., Jahnke, R. A., Owens, N. J. P., Pilson, M. E. Q., and Seitzinger, S. P.: The fate of nitrogen and phosphorus at the land-sea margin of the North Atlantic Ocean, in: Nitrogen Cycling in the North Atlantic Ocean and its Watersheds, edited by: Howarth, R., Springer Netherlands, 1996

Norkko, J., Reed, D. C., Timmermann, K., Norkko, A., Gustafsson, B. G., Bonsdorff, E., Slomp, C. P., Carstensen, J., and Conley, D. J.: A welcome can of worms?, Hypoxia mitigation by an invasive species, Glob. Change Biol., 18, 422-434, 2012.

Omstedt, A.: Guide to process based modeling of lakes and coastal seas, Springer Praxis-Books in Geophysical Sciences, 2015.

Oschlies, A., Blackford, J., Doney, S. C., and Gehlen, M.: Modelling considerations, in: Guide to best practices for ocean acidification research and data reporting, edited by: Riebesell, U., Fabry, V. J., Hansson, L., and Gattuso, J.-P., Publications Office of the European Union, 233-242, 2010.

Rabalais, N. N., Turner, R. E., and Wiseman Jr., W. J.: Gulf of Mexico hypoxia, AKA The dead zone, Annu. Rev. Ecol. Syst., 33, 235-263, 2002.

Robertson, L., Langner, J., and Engardt, M.: An Eulerian limitedarea atmospheric transport model, J. App. Meteorol., 38, 190$210,1999$.

Rosenberg, R. and Diaz, R. J.: Sulfur bacteria (Beggiatoa spp.) mats indicate hypoxic conditions in the inner Stockholm Archipelago, Ambio, 22, 32-36, 1993.

Sahlberg, J., Marmefelt, E., Brandt, M., Hjerdt, N., and Lundholm, K.: HOME - Vatten i Norra Östersjöns vattendistrikt, Integrerat modellsystem för vattenkvalitetsberäkningar, Swedish Meteorological and Hydrological Institute, Oceanografi, SMHI reports 93, 2008.
Sanders, R., Jickells, T., Malcolm, S., Brown, J., Kirkwood, D., Reeve, A., Taylor, J., Horrobin, T., and Ashcroft, C.: Nutrient fluxes through the Humber estuary, J. Sea. Res., 37, 3-23, 1997.

Sheldon, J. E. and Alber, M.: The calculation of estuarine turnover times using freshwater fraction and tidal prism models: a critical evaluation, Estuar. Coast., 29, 133-146, 2006.

Seitzinger, S. P. and Giblin, A. E.: Estimating denitrification in North Atlantic continental shelf sediments, Biogeochemistry, 35, 235-260, 1996.

Soetaert, K., Middelburg, J. J., Herman, P. M., and Buis, K.: On the coupling of benthic and pelagic biogeochemical models, EarthSci. Rev., 51, 173-201, 2000.

Strömqvist, J., Arheimer, B., Dahné, J., Donnelly, C., and Lindström, G.: Water and nutrient predictions in ungauged basins: set-up and evaluation of a model at the national scale, Hydrol. Sci. J., 57, 229-247, 2012.

Svensson, U.: PROBE An instruction manual, SMHI, 1998.

Vahtera, E., Conley, D. J., Gustafsson, B. G., Kuosa, H., Pitkänen, H., Savchuk, O. P., Tamminen, T., Viitasalo, M., Voss, M., and Wasmund, N.: Internal ecosystem feedbacks enhance nitrogenfixing cyanobacteria blooms and complicate management in the Baltic Sea, AMBIO, 36, 186-194, 2007.

Viktorsson, L., Almroth-Rosell, E., Tengberg, A., Vankevich, R., Neelov, I., Isaev, A., Kravtsov, V., and Hall, P. O. J.: Benthic Phosphorus Dynamics in the Gulf of Finland, Baltic Sea, Aquat Geochem., 18, 543-564, 2012.

Voss, M., Emeis, K., Hille, S., Neumann, T., and Dippner, J.: Nitrogen cycle of the Baltic Sea from an isotopic perspective, Global Biogeochem. Cy., 19, GB3001, doi:10.1029/2004GB002338, 2005.

Xue, Z., He, R., Fennel, K., Cai, W.-J., Lohrenz, S., and Hopkinson, C.: Modeling ocean circulation and biogeochemical variability in the Gulf of Mexico, Biogeosciences, 10, 7219-7234, doi:10.5194/bg-10-7219-2013, 2013. 